ROGERIO MOLLICA

\title{
OS PROCESSOS REPETITIVOS E A CELERIDADE PROCESSUAL
}

\section{DOUTORADO EM DIREITO}

Orientador: Prof. Titular José Roberto dos Santos Bedaque

Faculdade de Direito do Largo São Francisco - Universidade de São Paulo São Paulo - 2010 


\section{OS PROCESSOS REPETITIVOS E A CELERIDADE PROCESSUAL}

Tese apresentada à Banca Examinadora da Faculdade de Direito da Universidade de São Paulo, como exigência parcial, para obtenção do título de Doutor em Direito, na área de concentração: Direito Processual, sob a orientação do Prof. Titular José Roberto dos Santos Bedaque.

Faculdade de Direito do Largo São Francisco - Universidade de São Paulo São Paulo - 2010 


\section{RESUMO}

Este trabalho procura identificar os problemas ocasionados pelos processos repetitivos e buscar meios de compatibilizar a celeridade processual com o grande aumento do número de ações ajuizadas, sendo que grande parte dessas ações discutem teses idênticas.

A preocupação com o atraso na prestação jurisdicional não pode ser tida como uma exclusividade brasileira, mas um problema que afeta diversos países, sejam eles mais ou menos desenvolvidos. Vários países europeus passaram a prever em suas constituições e leis que a tramitação dos processos deve ocorrer num prazo razoável, sem dilações indevidas, e promoveram diversas reformas processuais, visando a diminuir a grande demora na tramitação dos processos judiciais.

$\mathrm{O}$ estudo mostra que os feitos repetitivos tratam principalmente de relações de consumo, de funcionários públicos em busca de reajustes passados, de contribuintes buscando afastar a cobrança de algum imposto, ou de ações visando à obtenção de benefícios na Previdência Social. Nesse pequeno quadro de ações repetitivas, pode-se verificar que os entes governamentais estão presentes direta ou indiretamente em todos eles. Os feitos repetitivos envolvendo a Fazenda Pública acabam por prejudicar a celeridade processual e essa demora parece interessar aos entes públicos que assim ganham tempo para efetuar pagamentos ou conceder benefícios. Muitos dos problemas levados pelos particulares ao Poder Judiciário poderiam e deveriam ser resolvidos administrativamente, pois o judiciário não pode se tornar uma extensão do balcão dos entes públicos.

Procura-se mostrar que o incentivo aos meios alternativos de solução de controvérsia pode ser uma melhor opção à celeridade processual do que o aumento do investimento no Poder Judiciário que, muitas vezes, acaba por gerar mais processos e saturação de nossos fóruns. 
Como, muitas vezes, não se mostra possível a diminuição dos feitos em tramitação, ou o aumento da estrutura judiciária para fazer frente à demanda crescente, é preciso que os escassos recursos sejam otimizados para que se possa aproveitar bem a estrutura disponível, para que se tenha uma prestação mais célere e com o emprego de menos recursos. Ademais, os precedentes devem ser valorizados, pois somente com a previsibilidade de julgamentos uniformes e que respeitem a segurança jurídica é que poderemos racionalizar o trabalho do judiciário e dar vazão aos milhões de processos que atolam as nossa Cortes.

Em seguida, passa-se ao estudo das novas técnicas do processo para que se consiga obter celeridade processual nos processos repetitivos. São revistas novidades legislativas como o artigo 285-A do CPC, a súmula vinculante e a impeditiva de recursos, o julgamento por amostragem, a ênfase no julgamento monocrático, bem como a informatização e os processos coletivos, como meios de assegurar uma rápida tramitação processual dos processos repetitivos.

Por fim, antes de alinhar as conclusões obtidas no decorrer do estudo, são analisados alguns projetos de lei e idéias apresentadas por doutrinadores de alterações legislativas, para a verificação de sua utilidade para equalizar a relação dos processos repetitivos com a celeridade que se busca na tramitação processual. Por fim, chega-se à conclusão de que é necessário que se dê um tratamento especial para os processos repetitivos para não inviabilizar o processo como um todo. 


\section{$\underline{\text { ABSTRACT }}$}

This paper aims at identifying problems provoked by repetitive proceedings, as well as finding means to harmonize proceeding speed with the great increase in the number of judged actions - and a large part of such actions discuss identical thesis.

The preoccupation with delays in legal assistance is not to be regarded as a Brazilian exclusivity, since it affects several countries with different degrees of development. Several European countries made their constitutions and laws provide that proceedings should happen within a reasonable time, with no undue delays, and promoted several proceedings alterations aiming at and diminishing great delay in legal proceedings.

This study shows that repetitive proceeds deal mainly with consuming relationships: civil servants trying to rescue past salary adjustments; taxpayers trying to avoid the charging of some tax; or actions aiming at benefits from the Social Assistance. Within this limited frame of repetitive actions it may be seen that government entities are directly or indirectly present in all of them. Repetitive actions involving the Ministry of Finance disturb proceeding speed, and this delay seems to be of interest for the public entities, which thus take their time to make payments and promote benefits. Many of the problems taken by citizens to the Judiciary could and should be solved in administrative terms, since the Judiciary cannot become an extension of the teller of public entities.

This paper tries to show that incentive to alternative means for the solution of controversies can be a better choice to speed up proceedings than increasing investments in the Judiciary, which often generates more proceedings and the saturation of our courts. 
As the decrease in procedures and the expansion of the judiciary structure are frequently impossible, it is necessary to optimize scarce resources in order to use the available structure well, in order to have a quicker and cheaper service. Besides, proceedings should be valued since only the predictability of uniform judgments respecting legal security might allow rationalizing work in the Judiciary, thus liberating millions of piles of proceedings accumulated in our Courts.

This paper then discusses the new proceeding techniques in order to obtain a greater speed in repetitive proceedings. Legal advances such as article 285-A of CPC, the linking summary, the sampling judgment, the emphasis on monocratic judgment, as well computerization and collective proceedings as ways of granting a quick procedure of repetitive proceedings, are reviewed.

Before presenting the conclusions obtained by this study, we analyze some bills and ideas proposed by indoctrinators of legal alterations for the checking of their applicability to equalize the relationship of repetitive proceedings with the desired speed in procedure. We finally conclude that it is necessary to give a special treatment to repetitive proceedings in order not to affect proceedings as a whole. 


\section{RIASSUNTO}

Questo lavoro cerca di identificare i problemi causati dai processi analoghi e di trovare i mezzi di compatibilizzare la celerità processuale con il grande aumento di azxioni agiudicate, essendo che gran parte di queste azioni discutono tesi identiche.

La preoccupazione con il ritardo nella prestazione giurisdizionale non può essere considerata come un'esclusività brasiliana, ma un problema che coinvolge diversi Paesi, siano loro più o meno sviluppati. Diversi Paesi dell'Europa hanno cominciato a prevedere nelle loro costituzioni e leggi che il tramite dei processi deve accadere in una durata ragionevole, senza dilazioni indovute e hanno promosso diverse riforme processuali con lo scopo di diminuire il grande ritardo nella tramitazione dei processi giudiziali.

Lo studio mostra che i fatti analoghi trattano inanzitutto di rapporti di consumo, di funzionari pubblici cercando arretratti dovuti, di contribuenti cercando di allontanare la riscossione di qualche tassa, o di azioni che mirano l'ottenimento di benefici nella Previdenza Sociale. In questo piccolo quadro di azioni analoghi, ci si può verificare che gli enti governativi sono presenti diretta od indirettamente in tutti loro. I fatti analoghi coinvolgendo la Pubblica Finanza finiscono per dannegiare la celerità processuale e questo ritardo pare interessare agli enti pubblici che così hanno tempo per effetuare pagamenti o concepire benefici. Molti dei problemi portati dai privati al Potere Giudiziario potrebbero e dovrebbero essere risolti amministrativamente, giacché il giudiziario non può diventare una estensione dei balconi degli enti pubblici.

Si cerca di mostrare che l'incentivo ai mezzi alternativi di soluzione di controversia può essere una opzione migliore alla celerità processuale anziche l'aumento dell'investimento nel Potere Giudiziario che, molte volte, finisce per scaturire più processi la saturazione dei fori. 
Come, molte volte, non si mostra possibile la diminuzione dei fatti in tramitazione, o l'aumento della struttura giudiziaria per far fronte alla domanda crescente, è necessario che le scarse risorse siano ottimizate affinché si possa approffitare bene la struttura disponibile, perché si abbia una prestazione più celere e con l'impiego di meno risorse. Inoltre, i precedenti devono essere valutati, sicché soltanto con la previsibilità di giudizi uniformi e che rispettino la sicurezza giuridica fa sì che potremo razionalizzare il lavoro e smaltire i milioni di processi che colmano le nostre Corti.

In seguito si passa allo studio delle nuove tecniche del processo affinché si riesca as ottenere celerità processuale nei processi analoghi. Sono reviste novità legislative come l'articolo 285-A del CPC, la sumola vincolante e la impeditiva di risorse, il giudizio per campione, l'enfasi nel giudizio monocratico, così come l'informatizzazione ed i processi colettivi, come mezzi di assicurare una rapida tramitazione processuale dei processi analoghi.

Infine, prima di allineare le conclusioni ottenute nel trascorso dello studio, sono analizzati alcuni disegni di legge e idee presentate da dotrinatori di alterazioni di legge per la verifica della loro utilità per equalizzare il rapporto dei processi analoghi con la celerità che si cerca nel tramite processuale. Alla fine, si arriva alla conclusione che è necessario che si dia una attenzione speciale ai processi analoghi per non inviabilizzare il processo come un tutto. 


\section{INTRODUÇÃO}

As recentes leis que modificaram o Código de Processo Civil mostraram uma preocupação muito clara de simplificar a tramitação dos processos, abreviando o seu curso e diminuindo o seu custo. Isto é, buscou-se dar uma maior efetividade ao processo ${ }^{1}$, especificamente à tutela jurisdicional.

Nos últimos anos, assistiu-se a um brutal aumento no número de processos ajuizados $^{2}$. Seja pelo maior conhecimento dos direitos por parte da população, pelo aumento da complexidade das relações na sociedade moderna e mesmo pela redução na capacidade de dialogar ${ }^{3}$, fato é que quase todos esses problemas são levados ao Judiciário.

\footnotetext{
${ }^{1}$ Segundo o professor Cândido Rangel Dinamarco, a efetividade do processo "constitui expressão resumida da idéia de que o processo deve ser apto a cumprir integralmente toda a sua função sócio-político-jurídica, atingindo em toda plenitude todos os seus escopos institucionais". Acrescenta o ilustre professor em outra passagem, que a "efetividade do processo, entendida como se propõe, significa a sua almejada aptidão a eliminar insatisfações, com justiça e fazendo cumprir o direito, além de valer como meio de educação geral para o exercício e respeito aos direitos e canal de participação dos indivíduos nos destinos da sociedade, assegurar-lhes a liberdade" A Instrumentalidade do Processo, $10^{\mathrm{a}}$ ed. São Paulo, Malheiros, 2002, p. 270/271. ${ }^{2}$ Ricardo Quass Duarte enumera que "a campanha de acesso à Justiça não foi a única responsável pela grande afluência de demandas ao Poder Judiciário, verificada recentemente. Além do natural crescimento populacional, que, por si só, seria suficiente para justificar o aumento da procura pela tutela jurisdicional, podem ser citadas como causas da ampliação da procura pelos serviços judiciais a conscientização de direitos pelos cidadãos, o aumento das transações civis e comerciais em quantidade e complexidade, o processo tecnológico, a proteção a novas espécies de direitos, os planos financeiros conjunturais, o aumento da produção legislativa, a redemocratização do país, a popularização da internet, o incremento do comércio eletrônico entre outras. Bug do milênio, violação a direito de imagem por e-mail, dano ambiental, desrespeito a direitos do consumidor, clonagem de cartão de crédito e fraudes em transações, on line constituem exemplos de novos temas que vieram aportar no Poder Judiciário, e, ao que tudo indica, esse rol será ampliado cada vez mais." (O Tempo Inimigo no Processo Civil Brasileiro, São Paulo, LTr, 2009, p. 70/71). Já o professor José Roberto Bedaque constata que a facilitação do ingresso no judiciário, decorrente das "ondas renovatórias" do processo civil, fez com as aumentasse "de forma espantosa" o número de processos. O Poder Judiciário, contudo não tem capacidade para absorvê-los, constituindo esta uma da das razões de sua ineficiência (Efetividade do Processo e Técnica Processual, São Paulo, Malheiros, 2006, p. 20/21).

${ }^{3}$ Segundo Fernanda Tartuce, o aumento no número de processos pode ser explicado pelo "incremento no direito à informação e o maior conhecimento dos indivíduos sobre suas posições de vantagem como reafirmações dos direito cívicos a quem fazem jus. A verificação dessa verdadeira emancipação da cidadania tem gerado uma ampla disposição de não mais se resignar ante as injustiças, o que acarreta um maior acesso às cortes estatais para questionar os atos lesivos; tal situação pode ser vista como uma 'síndrome de litigiosidade', sendo agravada pela redução da capacidade de dialogar verificada na sociedade contemporânea." (Mediação nos Conflitos Civis, São Paulo, Método, 2008, p. 28). O aumento no número de processos é um fenômeno mundial. Segundo o professor Italiano Frederico Carpi, as causas da crise da justiça no mundo seriam o aumento da litigiosidade, resultante de um maior dinamismo das relações econômicas, que não mais tolera atraso ou ineficiência; a inadequação da legislação às novas necessidades da sociedade; a falta de organização dos ofícios judiciários, a incompleta utilização das novas técnicas de informática e a carente formação dos magistrados e advogados. ("Le riforme del processo civile in Itália verso il XXI secolo", in Rivista Trimestrale di Diritto e Procedura Civile, ano LIV, n. 1, Milano, Giuffrè, 2000, p. 106/107).
} 
Logo, nossos fóruns estão repletos de causas, muitas vezes idênticas, e, dificilmente, consegue-se uma solução célere e eficiente no nosso Judiciário ${ }^{4}$. A publicação do Conselho Nacional de Justiça (CNJ) intitulada "Justiça em Números 2008"5 é clara ao apontar as dificuldades enfrentadas pelo nosso Judiciário. Em 2008, a Taxa de Congestionamento medida na Justiça Federal de $1^{a}$ instância foi de $76,1 \%$, chegando a $90,2 \%$ na $2^{a}$ Região (RJ e ES). Na $2^{\text {a }}$ instância, a taxa é de $59,8 \%$, sendo de $67,1 \%$ na $1^{\text {a }}$ Região e de $66 \%$ na $3^{\text {a }}$ Região (SP e MS). Na Justiça Estadual, o congestionamento médio é de $42,5 \%$ em $2^{\circ}$ grau e de $79,6 \%$ em $1^{\circ}$ grau, sendo que São Paulo possui a taxa de $84 \%$ e existem seis Estados com índices ainda piores. Sendo que a imensa maioria dos novos casos ajuizados são processos repetitivos.

No Brasil, existe um processo em tramitação para cada cinco cidadãos, um índice elevado que aparenta, em uma primeira análise, amplo e irrestrito acesso à Justiça. No entanto uma análise mais aprofundada mostra que não é esta a realidade. $\mathrm{O}$ alto índice de litigância no Judiciário brasileiro aponta apenas que um número muito pequeno de pessoas ou instituições utilizam intensamente o sistema, enquanto a maior parte da população não tem acesso a este meio formal de resolução de conflitos. Há um excesso de demandas judiciais que não decorre da democratização do acesso à Justiça, mas de sua utilização exagerada por poucos atores, dentre os quais o Poder Público, concessionárias de serviços públicos, prestadoras de serviços e instituições financeiras. Não há possibilidade de se pensar em reforma da Justiça sem refletir sobre o papel destes personagens e sobre como limitar seu acesso ao sistema judicial. ${ }^{6}$

\footnotetext{
${ }^{4}$ O investimento no Poder Judiciário não aumentou na mesma proporção que os processos. Assim, tanto a celeridade quanto a qualidade dos julgados ficam comprometidas. Esse fenômeno não ocorre somente em nosso país. Adrian A.S. Zuckerman esclarece que a qualidade do procedimento decorre dos recursos que são disponibilizados para o processo. Um sistema que conte com recursos insuficientes provavelmente será de inferior qualidade, ficando sujeito a gerar decisões que não primem pela justiça. É evidente que há outros fatores a influírem na obtenção de uma justiça justa, como a racionalidade do processo e a integridade dos juízes. Entretanto, quantos mais recursos forem investidos em instalações judiciárias, melhor a qualidade e maior a probabilidade de serem emanadas decisões que primam pela justiça. (in Justice in Crisis: Comparative Dimensions of Civil Procedure, New York, Oxford, 1999, p. 7).

${ }^{5}$ Disponível no site do CNJ <www.cnj.jus.br> , acesso em 04/01/2010.

${ }^{6}$ Cfr. o ex-secretário da Reforma do Judiciário do Ministério da Justiça, Pierpaolo Cruz Bottini em seu texto "Contornos da reforma contemporânea do processo civil", in Revista de Processo, n. 143, São Paulo, Revista dos Tribunais, 2007, p. 280.
} 
Entre as muitas alterações ao Código de Processo Civil, viu-se recentemente uma grande preocupação com essas Ações Repetitivas. ${ }^{7} \mathrm{O}$ que se almeja analisar é como compatibilizar a celeridade processual com o vertiginoso aumento das demandas ajuizadas, principalmente das chamadas Ações Repetitivas. ${ }^{8}$

Receptivo às exigências da sociedade por um processo civil mais efetivo e dinâmico, buscou-se no presente trabalho, na medida do possível, rever os principais trabalhos doutrinários publicados em nosso país e no estrangeiro ${ }^{9}$, assim como os novos projetos de lei e a jurisprudência de nossos tribunais acerca dos temas abordados.

\footnotetext{
${ }^{7}$ Segundo Alexandre Gustavo Melo Franco Bahia e Dierle José Coelho Nunes: "Não se pode olvidar que na atualidade a ciência processual precisa lidar, de modo a viabilizar uma aplicação legítima e eficiente (efetividade normativa), com três tipos de litigiosidade: a individual ou 'de varejo' ou 'de baixa intensidade': sobre a qual o estudo e dogmática foram tradicionalmente desenvolvidos, envolvendo lesões e ameaças a direito isoladas; b) a litigiosidade coletiva: envolvendo direitos coletivos e difusos, nos quais se utilizam procedimentos coletivos, representativos, normalmente patrocinados por legitimados extraordinário (órgão de execução do MP, associações representativas, etc.); e c) em massa ou de alta intensidade: que dá margem à propositura de ações repetitivas ou seriais, que possuem como base pretensões isomórficas, com especificidades, mas que apresentam questões (jurídicas e /ou fáticas) comuns para a resolução da causa." ("Por um renovado paradigma processual", in Revista IOB de Direito Civil e Processo Civil, n. 60, São Paulo, IOB, 2009, p. 80/81. Prosseguem os autores defendendo ser extremamente difícil a criação de uma dogmática de tratamento comum dos três tipos de litígio sob pena de inviabilizar uma aplicação jurídica consentânea com o modelo constitucional do processo. (p. 81).

${ }^{8}$ Em Portugal, as Ações Repetitivas têm sido vistas de uma forma negativa, pois segundo Mariana França Gouveia "Desde 1993, ano em que foi publicado o diploma que criou a injunção, que a litigância de massa tem sido estigmatizada. Parece querer passar-se a idéia de que é uma coisa horrível, que a culpa da sua existência é dos credores, que devem de algum modo ser penalizados, que trabalhar nesta área, sejam os profissionais em causa juízes ou advogados, é uma espécie de vergonha. Pois, caro leitor, a litigância de massa, a litigância de pequenas dívidas é o produto directo da sociedade de consumo em que vivemos. É o produto directo de uma realidade sociológica de desenvolvimento econômico - de bem estar. Os autores deste tipo de acções são, na sua maioria, as empresas que criam emprego e fazem o desenvolvimento econômico do país. Penalizá-las? Fazê-lo implica apenas aumentar os custos do seu serviço, ou seja, penalizar-nos a nós que o compramos e pagamos. Uma concepção paternalista do consumidor prejudica-nos a todos, desresponsabiliza-nos a todos, faz com que hoje a 'culpa' e a 'responsabilidade'seja sempre de todos, desde que não seja minha." ("A acção especial de litigância de massa" in Novas Exigências do Processo Civil, Coimbra Editora, 2007, p. 151/152).

${ }^{9} \mathrm{O}$ professor Italiano Vincenzo Vigoriti adverte que o direito pode ser estudado por métodos comparativos, fato que suscita tanto entusiasmo como resistência. A postura de fechamento às influências estrangeiras (horror alieni iuris) é mais antiga e o entusiasmo mais recente, sendo que a prudência e o equilíbrio se mostram vitais nesse caso: "Tuttavia, l'invito alla prudenza è d'obbligo. Il método comparativo ha insospettabili difficoltà e l'incomprensione è rischio assai concreto. Ci si trova costantemente di fronte a problemi linguistici, di individuazione del quadro normativo, di collocazione del dato giurisprudenziale, di percezione del sostrato degli istituti, e dei motivi delle scelte. Il che non può indurre a pretendere che Il comparatista debba prima acquisire contezza delle ragioni economico-filosofiche, e sociali degli istituti stranieri, che è pretesa ovviamente eccessiva e frustrante, mai avanzata nei confronti dei cultori del solo diritto nazionale. Ma è invito a cautela e prudenza prima di incamminarsi per strade più impervie di quanto all'inizio si possa immaginare." ("Di alcuni recenti interventi sul diritto comparato", in Revista de Processo, n. 154, São Paulo, Revista dos Tribunais, 2007, p. 97).
} 
De fato, a Emenda Constitucional no 45 (Reforma do Judiciário) passou a prever a existência de Súmulas Vinculantes e a necessidade de Repercussão Geral para a admissão de Recursos Extraordinários; a Lei no 11.276/2006 previu a existência de Súmulas Impeditivas de Recursos e a Lei no 11.277/2006 incluiu o artigo 285-A ao Código de Processo Civil, para prever a rejeição liminar de ações que afrontem decisões proferidas em casos idênticos aos já julgados anteriormente pelo juízo. Já o julgamento por amostragem $^{10}$ é inovação recente, com a inclusão dos artigos 543-B e 543-C ao Código de Processo Civil (CPC).

Tais reformas esparsas não foram suficientes e hoje já se projeta a elaboração de um novo Código de Processo Civil. Para tal fim, o Senado Federal instituiu uma comissão de juristas, presidida pelo Ministro Luiz Fux, tendo na relatoria a professora Teresa Arruda Alvim Wambier e que tem como membros, dentre outros, professores do quilate de Humberto Theodoro Júnior, José Roberto dos Santos Bedaque, Adroaldo Furtado Fabrício e Paulo Cezar Pinheiro Carneiro. No esboço, já apresentado ao presidente do Senado Federal, ficou clara a grande preocupação que os membros tiveram com os processos repetitivos, sendo prevista a inclusão do incidente de coletivização da tutela para causas "idênticas" e o maior respeito aos precedentes, com a vinculação dos julgados por amostragem produzidos pelo Superior Tribunal de Justiça. Ao longo do presente trabalho tais proposições serão objeto de análise.

É claro que a maioria dos problemas enfrentados pelos processos não são legislativos, mas sim estruturais ${ }^{11}$ e culturais, portanto, somente alterações legislativas não serão suficientes para que se tenha um processo célere e eficaz. Durante o trabalho, procurar-se-á mostrar que o problema é multifacetário e, se o foco somente se der sobre uma das causas dos problemas, dificilmente teremos uma solução e sobrarão mais frustrações, além do sentimento de impotência que paira sobre todos os operadores do direito.

${ }^{10}$ A expressão foi cunhada pelo professor José Carlos Barbosa Moreira em seu artigo "Súmula, jurisprudência, precedente: uma escalada e seus riscos", in Revista Dialética de Direito Processual, n. 27, São Paulo, Dialética, 2005, p. 53.

${ }^{11}$ Segundo Flávia de Almeida Montingelli Zanferdini “Temos legislação processual de primeiro mundo a ser aplicada com recursos de terceiro mundo, por um Poder Judiciário desprestigiado, criticado e sem recursos. O Judiciário carece, com urgência, de recursos materiais e humanos para atender devidamente à demanda por seus serviços, portanto, precisa ser aparelhado de forma adequada e suficiente para fazer cumprir a garantia do término do processo em tempo razoável." ("A crise da justiça e do processo e a garantia do prazo razoável", in Revista de Processo, n. 112, São Paulo, Revista dos Tribunais, 2003, p. 244). 
A sociedade atual é fortemente marcada pelo fenômeno da repetição. Tal fenômeno se faz presente em praticamente todos os setores da vida contemporânea, produzindo uma verdadeira massificação das relações econômicas e sociais, com naturais reflexos nos litígios surgidos no seu contexto. Na medida em que uma similar relação de consumo se repete inúmeras vezes, eventual abusividade gerará danos e processos nessa mesma escala. $^{12}$

São incontáveis as dúvidas e aflições que a avalanche de processos repetitivos gera em todos os operadores e estudiosos do direito. As Ações Repetitivas, sejam as que discutem Direito do Consumidor, Direito Tributário ou Previdenciário, crescem em progressão geométrica e podem acabar inviabilizando a já problemática prestação efetiva da atividade jurisdicional.

O professor Cândido Rangel Dinamarco foi muito feliz ao analisar os problemas que os processos repetitivos vêm causando ao judiciário. De fato, segundo o Mestre:

\begin{abstract}
"No sistema do common law costuma ser dito que a força vinculante dos holdings (máximas contidas nos julgamentos) propicia a quádrupla vantagem expressa nas palavras igualdade-segurança-economiarespeitabilidade. Vendo agora o avesso representado pela imensa fragmentação de julgados presente na realidade brasileira, tem-se que nos julgamentos repetitivos e absolutamente desvinculados residem fatores que podem comprometer cada um desses ideais da boa justiça, porque (a) somente os que puderem e se animarem a subir ao Supremo Tribunal Federal ou ao Superior Tribunal de Justiça poderão afastar de si os julgamentos desfavoráveis suportados nas instâncias locais, (b) por isso mesmo ou por outros fatores, reinará sempre entre os jurisdicionados alguma incerteza sobre o futuro dos litígios em que se
\end{abstract}

\footnotetext{
${ }^{12}$ Cfr. Luis Guilherme Aidar Bondioli in "A Nova Técnica de julgamento dos Recursos Extraordinário e Especial Repetitivos", 2009, inédito, p. 1. Para o Professor Sidnei Agostinho Beneti "A economia em escala, a documentação, a informática e a comunicação eletrônica produziram no Judiciário o resultado da geração de números elevados de recursos relativos a lides individuais idênticas. A individualização, entretanto, é mais aparente do que real. Integram elas, em verdade, a mesma macrolide socioeconômica. É o que se dá nas ações envolvendo entes jurídicos de intensa prática negocial repetitiva, geralmente, no âmbito privado, instrumentalizadas por contratos de adesão e, no âmbito público, pelo relacionamento jurídico decorrente de situações administrativas e tributárias que produzam conseqüências relativamente à pluralidade de sujeitos." (“Assunção de Competência e fast-track recursal” in Revista de Processo, n. 171, São Paulo, Revista dos Tribunais, 2009, p. 10).
} 
acham envolvidos, (c) o Poder Judiciário prossegue envolvido em um trabalho inútil e repetitivo, quando poderia libertar-se da carga da repetição e dedicar-se com maior proficiência e celeridade a outros casos, $e(d)$ as decisões do órgão competente para dada matéria ficariam sempre prestigiadas, prevalecendo soberanas e com homogeneidade em todos os casos." ${ }^{\prime 13}$

Procurar-se-á mostrar que não são todos os litígios que deveriam ser obrigatoriamente levados à apreciação do Judiciário. A leitura precipitada do artigo $5^{\circ}$, XXXV, da Constituição Federal pode levar à conclusão de que tudo pode e deve ser apreciado pelo Poder Judiciário, fechando as portas para outros meios de soluções de controvérsia e agravando ainda mais a crise do Poder Judiciário e a celeridade almejada por todos. $^{14}$

${ }^{13}$ In "Súmulas vinculantes", Revista Forense, v. 347, Rio de Janeiro, 1999, p. 53/54.

14 Outro não é o entendimento do Professor Rodolfo de Camargo Mancuso, para quem: "O fato da crise numérica de processos não arrefecer, apesar da prolongada reforma da lei processual, é forte evidência de que não se consegue debelar as carências e deficiências do sistema através da singela nomocracia, até porque a edição de novas leis implica o surgimento de novas dúvidas e controvérsias, num perverso círculo vicioso. Tal política legislativa, para surtir efeito, teria de ser acompanhada do reconhecimento da verdadeira causa do problema - a cultura demandista, à sua vez insuflada pela percepção prodigalizada (e equivocada) do acesso à Justiça -, por modo que tal constatação pudesse inculcar a vontade política de alterar o quadro existente, a começar pela necessária informação ao público-alvo (os jurisdicionados) quanto aos ônus e encargos do processo judicial e, bem assim, quanto aos outros modos de prevenir e resolver controvérsias. É dizer, impende desconstruir a premissa - dogmatizada à custa de ser repetida - de que a via judicial é o escoadouro natural de toda e qualquer pretensão resistida ou insatisfeita, discurso populista que leva a generalizar (e banalizar) o serviço judiciário estatal, em modo de uma porta larga e franqueada incondicionalmente a cada petição que um sedizente prejudicado entenda apresentar ao guichê do Fórum. Essa cultura, aderente a uma percepção distorcida da justiça oficial, é o que verdadeiramente está á base da crise numérica de processos, não só pelo estímulo à contenciosidade social, como também por impedir que larga parcela dos conflitos deixe de ser encaminhada para outros agentes, órgãos e instâncias, o que aliviaria consideravelmente a carga que hoje assoberba a Justiça estatal e a impede de ofertar uma resposta de qualidade: justa, jurídica, econômica, tempestiva e razoavelmente previsível." (“A resolução dos conflitos e a função judicial no contemporâneo Estado de Direito (nota introdutória), in Revista dos Tribunais, n. 888, São Paulo, Revista dos Tribunais, 2009, p. 23). Marco Antônio Garcia Lopes Lorencini também aponta que "Mais tarde, o que ficou conhecido como ADR movement elegeu como objetivos: atacar os custos e a demora nos tribunais; realçar o envolvimento da comunidade no procedimento de resolução de controvérsias, facilitar o acesso à justiça e propiciar maior efetividade à solução de controvérsias. Segundo essa linha de raciocínio, se mais e mais controvérsias continuassem a ser canalizadas para o Poder Judiciário, isso provocaria o congestionamento dos tribunais e sua conseqüente lentidão, daí a resposta no uso de meios alternativos. De nada adianta aparelhar os tribunais, pois o volume de demandas seria invencível, porque jamais proporcional à estrutura dos tribunais, por mais investimentos que possam ser feitos e juízes recrutados." ("A contribuição dos meios alternativos para a solução das controvérsias", in As grandes transformações do Processo Civil Brasileiro: Homenagem ao Professor Kazuo Watanabe, coord. Carlos Alberto Salles, São Paulo, Quartier Latin, 2009, p. 613/614). 


\section{A valorização dos precedentes $^{15}$ parece ser o caminho que vem sendo} trilhado pelo nosso ordenamento para fazer frente ao aumento descomunal do número de feitos ajuizados. O respeito aos precedentes mostra-se importante para a manutenção do princípio da igualdade e da segurança, representado pela previsibilidade do resultado final de teses já consolidadas em nosso Judiciário ${ }^{16}$. Ademais, a par do poder judiciário estar repleto de processos repetitivos, o tema ainda se mostra pouco estudado e só agora começa a ser esmiuçado pela doutrina.

\footnotetext{
${ }^{15} \mathrm{O}$ professor Americano Charles D. Cole conclui o seu artigo "Stare decisis na cultura jurídica dos Estados Unidos. O sistema de precedente vinculante do common law" (Revista dos Tribunais, ano 87, v. 752, 1998, p. 20/21) atestando que "o uso do precedente vinculante na cultura jurídica nos Estados Unidos, tanto no judiciário federal quanto estadual, é um dos atributos mais notáveis do direito americano. Precedente vinculante, tal como usado nos Estados Unidos, fornece uma base para que estudantes de direito, advogados, professores de direito e legisladores possam prever o que a Corte deverá decidir num caso sujeito a um precedente estabelecido. (...) O precedente vinculante é de boa utilidade para a cultura jurídica dos Estados Unidos, tornando o direito de casos uniforme e previsível na maioria das vezes, sem inibir a evolução. Assim sendo, o método de ensino jurídico e o sistema de apoio necessários para o uso eficaz do precedente jurídico nos Estados Unidos são, na opinião do autor, justificados pela estabilidade e previsibilidade das decisões judiciais que a doutrina do precedente vinculante torna possível."

${ }^{16}$ Segundo Luiz Guilherme Marinoni, "não há como esquecer da falta de racionalidade em obrigar alguém a propor uma ação para se livrar dos efeitos de uma lei que em inúmeras vezes já foi afirmada inconstitucional pelo judiciário. Note-se que o sistema que admite decisões contrastantes estimula a litigiosidade e incentiva a propositura de ações, pouco importando se o interesse da parte é a constitucionalidade ou a inconstitucionalidade da lei. Ou seja, a ausência de previsibilidade, como consequiência da falta de vinculação aos precedentes, conspira contra a racionalidade da distribuição da justiça e contra a efetividade da jurisdição. ("Aproximação crítica entre as jurisdições de civil law e de common law e a necessidade de respeito aos precedentes no Brasil", in Revista de Processo, n. 172, São Paulo, Revista dos Tribunais, 2009, p. 218). Em outro texto o Autor volta ao tema defendendo que "afirmar que o juiz tem o direito de julgar de forma diferente aos tribunais superiores constitui gritante equívoco. Se é o Superior Tribunal de Justiça quem dá a última palavra em relação à interpretação da lei federal, qual é a racionalidade de se dar ao juiz o poder de proferir uma decisão que lhe seja contrária? Basta perguntar quem tem razão, diante do sistema judicial, diante de uma súmula do Superior Tribunal de Justiça: é claro que aquele que tem o seu direito reconhecido na súmula. Portanto, decidir de forma contrária à súmula apenas obriga à interposição de recurso, consumindo mais tempo e despesas, seja da administração da justiça, seja do próprio cidadão. Sendo assim, a afirmação da prerrogativa de o juiz decidir de "forma diferente" do entendimento fixado pelos tribunais superiores, longe de ser algo que tenha a ver com a consciência do magistrado, constitui um ato de falta de compromisso com o Poder Judiciário, que deve estar preocupado, dentro do seu sistema de produção de decisões, com a efetividade e a tempestividade da distribuição da justiça. E não só um ato de falta de compromisso com o Judiciário, mas também um ato que atenta contra a cidadania, pois desconsidera o direito constitucional à razoável duração do processo." ("Ações Repetitivas e julgamento liminar", in Direito $e$ Processo: Estudos em Homenagem ao Desembargador Norberto Ungaretti, Coord. Pedro Manoel Abreu e Pedro Miranda de Oliveira, Florianópolis, Conceito Editorial, 2007, p. 675).
} 
É claro que o aumento vertiginoso dos processos repetitivos, além de prejudicar a celeridade processual, acaba por prejudicar a qualidade das decisões ${ }^{17}$. Com pouco tempo para ater-se a cada decisão, o julgador certamente incide em mais erros e é comum que questões não repetitivas sejam julgadas como o "modelo repetitivo", somente pela triagem do caso não ter sido bem feita, ou por guardar alguma similaridade com a tese de massa. Logo, sempre se mostra necessário o equilíbrio entre a celeridade e a segurança jurídica $^{18}$, que muitas vezes não se mostra fácil, já que celeridade não pode ser confundida com precipitação, e segurança não pode ser confundida com eternização. ${ }^{19}$

Para discorrer acerca dos Processos Repetitivos e da Celeridade Processual, optou-se por dividir o presente trabalho em duas principais partes, conforme abaixo exposto.

Na primeira delas, como não poderia deixar de ser, até para que o leitor se volte ao tema que será desenvolvido, procurou-se, de forma singela, perfazer um esboço histórico dos processos repetitivos e do papel dos precedentes, com uma visão do direito estrangeiro sobre o assunto, que procurará mostrar que a preocupação com os processos repetitivos e a celeridade processual também atinge outros ordenamentos. Serão ainda analisados os processos repetitivos, suas maiores causas e partes. Advertindo-se, desde já,

\footnotetext{
${ }^{17}$ Segundo o Professor Rodolfo de Camargo Mancuso, "o déficit de qualidade na resolução dos conflitos em nosso país deriva de três fatores:(i) política judiciária calcada no incessante aumento da estrutura física; (ii) avaliação de desempenho por critério quantitativo (in put e out put de processos); (iii) tendência à judicialização dos conflitos, e o seu corolário resistência aos (ou desconhecimento de) outros modos de resolve-los." "“A resolução dos conflitos e a função judicial no contemporâneo Estado de Direito (nota introdutória)!, in Revista dos Tribunais, n.888, São Paulo, Revista dos Tribunais, 2009, p. 11).Segundo o professor Sidnei Agostinho Beneti, as macrolides ou processos repetitivos "são sem sombra de dúvida, os principais responsáveis pela morosidade do funcionamento de todo aparelhamento judiciário brasileiro na atualidade e, ainda, determinadores da visível perda de qualidade da prestação jurisdicional atual, mesmo no caso de julgamento de assinatura ilustre de magistrados notoriamente munidos da melhor cultura jurídica e com passado jurisdicional firmado pela aplicação e cuidado na realização da melhor justiça." ("Assunção de Competência e fast-track recursal" in Revista de Processo, n.171, São Paulo, Revista dos Tribunais, 2009, p.12).

${ }^{18}$ Para o professor José Roberto dos Santos Bedaque, processo efetivo é aquele que, observado o equilíbrio entre os valores segurança e celeridade, proporciona às partes o resultado desejado pelo direito material. (Efetividade do processo e técnica processual, São Paulo, Malheiros, 2006, p. 49). Entretanto, o Mestre adverte que "a propósito da verdadeira cruzada em prol da celeridade do processo - nova obsessão de alguns - é preciso ser cauteloso, pois há risco de que outro valor extremamente importante acabe em segundo plano. Tão importante quanto acabar com a morosidade excessiva é preservar a segurança proporcionada pelo devido processo legal. Temos de-e está é nossa missão-encontrar o ponto de equilíbrio entre ambos" (p. 48).

${ }^{19}$ Cf. advertência de Fernando da Fonseca Gajardoni in "O princípio constitucional da tutela jurisdicional sem dilações indevidas e o julgamento antecipadíssimo da lide (artigo 285-A do CPC)", in As grandes transformações do Processo Civil Brasileiro: Homenagem ao Professor Kazuo Watanabe, coord. Carlos Alberto Salles, São Paulo, Quartier Latin, 2009, p. 999.
} 
que a adequada compreensão do que seriam os processos repetitivos e seu impacto sobre o processo mostrar-se-á imperiosa para o prosseguimento do estudo a ser implementado.

Se, por um lado, procurou-se desenvolver um estudo histórico e do direito estrangeiro consistente, por outro, é imprescindível reconhecer e alertar que estes tópicos do trabalho não ambicionam ser conclusivos acerca dos temas tratados, até porque foram concebidos como mero acessório ao estudo que se pretende levar a efeito.

A primeira parte do trabalho também é destinada a perfazer uma análise do judiciário em nosso país e no exterior, mostrando que os problemas com a celeridade processual não são uma exclusividade do nosso sistema, bem como demonstrar como os processos repetitivos colaboram enormemente para que não se tenha celeridade processual, com o consequente emperramento do Poder Judiciário.

Já na segunda parte do trabalho acontecerá o estudo das técnicas do processo para se obter celeridade processual nos processos repetitivos ${ }^{20}$, com a análise das recentes alterações legislativas já perpetradas para fazer frente ao descomunal aumento no número de processos, principalmente dos processos repetitivos. Em cada uma das inovações legislativas procurar-se-á mostrar a experiência de países estrangeiros e as principais dúvidas que ainda pairam sobre elas. Também são revistas algumas propostas de alterações legislativas para a verificação de sua utilidade para abreviar e simplificar a tramitação processual.

Como encerramento e ao final das duas principais partes em que foi dividida a presente tese, são alinhadas as principais conclusões verificadas no desenvolver do presente estudo, as quais, na maioria das vezes, reproduzem, de forma sintética e ordenada, posicionamentos tomados ao longo do próprio trabalho.

\footnotetext{
${ }^{20}$ Causas de massa exigem soluções de massa. O Ministro do Superior Tribunal de Justiça, Sidnei Agostinho Beneti, entende que "Em época de sociedade de massas, não há mais como imaginar a satisfação jurisdicional apenas em cada caso concreto, e de modo contraditório. A comunicação social, divulgando, em massa, a contradição, destrói a crença no Poder Judiciário e incrementa o surgimento de lides, realimentando-se a si própria. O Brasil precisa de construção de jurisprudência capaz do respeito da sociedade, não mais apenas de produção de precedentes individuais. A melhor organização dos tribunais é imprescindível ao aprimoramento da sociedade brasileira." ("Doutrina de precedentes e Organização Judiciária", in Processo e Constituição: Estudos em Homenagem ao Professor José Carlos Barbosa Moreira (Coordenação Luiz Fux, Nelson Nery Júnior e Teresa Arruda Alvim Wambier). São Paulo, Revista dos Tribunais, 2006, p. 485).
} 


\section{CONCLUSÃO}

Assim, deve-se estudar as Ações Repetitivas sob a ótica do processualista moderno, que tem a difícil missão de adequar o sistema processual para que se obtenha uma decisão célere e segura.

Conforme visto, nem todos os problemas da morosidade do judiciário podem ser resolvidos por meio de reformas processuais, pois a maioria dos problemas é estrutural e demanda um maior investimento governamental no Poder Judiciário. Muitas vezes, não interessa ao Poder Executivo investir no Judiciário, pois como se sabe, o Poder Público é o maior litigante e, na maioria das vezes, é o perdedor das demandas, assim a morosidade judicial acaba sendo interessante para que os pagamentos demorem a ser feitos. A recente Emenda Constitucional $n^{\circ} 45$ foi um primeiro passo para a reforma do judiciário, mas ainda muito há de ser feito para que se tenha um processo realmente efetivo.

Faz-se urgente um melhor estudo e adequação do nosso ordenamento processual em face do aumento vertiginoso das Ações Repetitivas, que já inviabilizaram os Juizados Especiais e podem vir a comprometer a celeridade do Judiciário como um todo.

É de suma importância dar maior valor aos precedentes judiciais e que eles sejam respeitados pelo próprio tribunal que o prolatou e pelos juízes vinculados a esse tribunal. Somente com a previsibilidade de julgamentos uniformes e que respeitem a segurança jurídica é que poderemos racionalizar o trabalho do judiciário e dar vazão aos milhões de processos que atolam as nossa Cortes. Não cabe mais indagar que o juiz tem o seu livre convencimento abalado, no caso de dever decidir de acordo com os precedentes dos Tribunais Superiores. Não faz sentido o juiz decidir de forma completamente contrária aos julgados dos Tribunais Superiores e obrigar a parte a despender tempo e dinheiro para alcançar essas Cortes para, só então, ter reconhecido o seu direito, que já deveria ter sido assegurado pelo juiz de primeiro grau. A falta de previsibilidade afeta todo o sistema e eterniza os processos, pois sempre a parte se vê convidada a recorrer, apostando na mudança de um entendimento até então consolidado. 
Desde muito, a influência, não vinculante, mas persuasiva, de decisões passadas não é estranha ao sistema Brasileiro. Trata-se de herança do velho direito português, desde as Ordenações do Reino, através dos assentos da casa de Suplicação de Lisboa e dos Supremos Tribunais de Justiça de Portugal e do Brasil, este último no império. A força vinculante dos precedentes também não pode ser tida como uma novidade, já que estava prevista nas Ordenações Manuelinas e Filipinas e da Lei na Boa Razão. A ideia de súmula de jurisprudência predominante surgiu em 1963, pelo espírito inovador do Ministro Victor Nunes Leal, do Supremo Tribunal Federal. Já a noção de súmula com efeito vinculante veio a ganhar impulso com a criação da ação declaratória de constitucionalidade, introduzida em nosso ordenamento jurídico pela Emenda Constitucional $n^{\circ} 3 / 93$.

A preocupação com o atraso na prestação jurisdicional não pode ser tida como uma exclusividade brasileira, mas um problema que afeta diversos países, sejam eles mais ou menos desenvolvidos. Vários países europeus passaram a prever em suas constituições e leis que a tramitação dos processos deve ocorrer num prazo razoável, sem dilações indevidas. Dentre esses países, destacam-se Portugal, Espanha e Itália, que vêm promovendo diversas reformas processuais, visando a diminuir a grande demora na tramitação dos processos judiciais.

Portugal aprovou, em 05 de maio de 2005, um Plano de Ação para o Descongestionamento dos Tribunais, com diversas medidas judiciais e pré-judiciais $\mathrm{O}$ Regime Processual Experimental criado pelo Decreto-Lei no 108/2006 prevê, entre outras medidas, assegurar um tratamento específico, no âmbito dos meios jurisdicionais, aos litigantes de massa, incluindo a previsão de decisões judiciais que abranjam vários processos. O Regime Processual Experimental foi bem recebido e teve até o seu prazo de dois anos prorrogado, e estatísticas recentes comprovam que ele ajudou a reduzir o tempo de tramitação dos processos sujeitos ao referido Regime. 
Nos últimos anos, temos assistido a um vertiginoso aumento no número de ações judiciais em tramitação. Como as ações crescem numa proporção muito maior do que o investimento estatal na Justiça, a cada ano temos um substancial represamento de ações e um maior comprometimento na celeridade processual.

Dentro dessas novas ações ajuizadas, a imensa maioria trata de assuntos repetitivos e já julgados à exaustão por nossos Tribunais. Trata-se principalmente de ações sobre relação de consumo, de funcionários públicos em busca de reajustes passados, de contribuintes buscando afastar a cobrança de algum imposto ou de ações visando à obtenção de benefícios junto à Previdência Social. Neste pequeno quadro de ações repetitivas, pode-se verificar que os entes governamentais estão presentes direta ou indiretamente em todos eles. Os feitos repetitivos envolvendo a Fazenda Pública (estimados em mais de $85 \%$ dos processos que tramitam em nossos Tribunais Superiores) acabam por prejudicar a celeridade processual e essa demora parece interessar aos entes públicos que assim ganham tempo para efetuar pagamentos ou conceder benefícios.

Grande parte dos processos que tramitam em nossos Fóruns são Execuções Fiscais. Estatísticas confiáveis demonstram que aproximadamente $50 \%$ dos processos se referem a executivos fiscais. Entretanto grande parte desses executivos Fiscais são ajuizados muito tempo depois do não pagamento dos débitos, não sendo mais possível localizar o devedor ou localizar bens disponíveis à satisfação do crédito reclamado. Assim, até por ineficiência dos entes Públicos, são ajuizadas milhões de Execuções Fiscais "próforma”, que desde logo se sabe que não lograrão êxito, só para que a prescrição não ocorra na mão da administração pública. Logo, teremos um sério comprometimento em nosso Poder Judiciário, e em troca, os entes Públicos não conseguem arrecadar nem 1\% do estoque total da dívida ativa. Assim, já passou da hora de se rever a Lei de Execuções Fiscais e esses procedimentos dos entes Públicos, para que se consiga maximizar a relação entre esforço do judiciário e valores arrecadados. Dada a ausência de estrutura da Administração Pública, o projeto de nova Execução Fiscal, que prevê a constrição Administrativa dos bens, mostra-se perigoso e indesejável, parecendo melhor o projeto que prevê que as execuções fiscais só poderiam ser ajuizadas com a indicação de bens passíveis de garantir o débito executado. 
A Emenda Constitucional $\mathrm{n}^{\circ}$ 45, de 08/12/2004, elevou a celeridade processual à categoria de garantia constitucional, introduzindo o inciso LXXVIII ao artigo $5^{\circ}$ da Carta Magna ao prever: "A todos, no âmbito judicial e administrativo, são assegurados a razoável duração do processo e os meios que garantam a celeridade de sua tramitação". Como é notório, o grande litigante em todas as esferas do judiciário é o Poder Público. Além do grande número de feitos, os entes Públicos acabam por piorar ainda mais a lentidão dos nossos Tribunais por eternizarem os processos. De fato, como se sabe o Poder Público se utiliza de todos os recursos disponíveis (até por dever de ofício de seus Procuradores) para procrastinar o trânsito em julgado da sentença no processo de conhecimento. Depois, muitas vezes, deixa de pagar a sua condenação por via do precatório, criando mais incidentes processuais e ajudando a atravancar ainda mais o Judiciário e abalar a credibilidade e o prestígio deste Poder junto à população.

O Judiciário não pode se tornar um mero prolongamento do balcão dos entes públicos. Questões como a concessão e o aumento de benefícios devem ser resolvidas administrativamente. Os entes públicos têm de aplicar com isenção as previsões legais e não com interpretações restritivas e ilegais. Tem de existir um contencioso administrativo célere e isento para dirimir essas questões e não um processo administrativo viciado e que sempre vai tender a dar a vitória ao ente público, obrigando a parte contrária a recorrer ao Judiciário para ver salvaguardado os seus direitos.

Além de o Poder Público como litigante contumaz, a celeridade processual é comprometida por vários outros fatores, sejam eles internos ou externos ao processo. Como fatores externos ao processo, temos as deficiências estruturais, que acabam por prejudicar a celeridade processual e a efetiva prestação jurisdicional. Um primeiro problema seria a falta de verbas e de autonomia financeira do Poder Judiciário. Além da falta de verba, muitas vezes, o dinheiro é mal empregado, pois a gestão dos Tribunais é feita pelos próprios Magistrados, que apesar de toda a boa vontade, não recebem qualquer treinamento para as tarefas administrativas. Assim, mostra-se urgente a profissionalização da administração da Justiça, com magistrados julgando processos, e pessoas especializadas cuidando das funções administrativas. 
Mostra-se ainda necessário um maior investimento em tecnologia e na contratação e qualificação do pessoal (funcionários e juízes). Também não bastam novas leis e maiores investimentos em instalações e pessoal se não ocorrer a mudança na mentalidade dos operadores do direito. É necessário que todos tenham em mente a importância de um processo seguro, célere e sem dilações indevidas. Faz-se também necessário afastar a cultura do atraso da mente dos operadores do direito para que finalmente possamos obter a celeridade processual.

No $2^{\circ}$ Encontro Nacional do Judiciário, realizado em fevereiro de 2009, em Belo Horizonte, o Conselho Nacional de Justiça (CNJ) lançou dez metas para melhoria do Poder Judiciário, visando à obtenção de maior agilidade na prestação jurisdicional e a melhoria do acesso da população à Justiça. Dentre as metas traçadas, sem dúvida, a que recebeu maior destaque foi a de $n^{\circ} 2$, uma vez que objetiva identificar os processos judiciais mais antigos e adotar medidas concretas para o julgamento de todos os feitos que foram distribuídos até 31/12/05 (em $1^{\circ}$ e $2^{\circ}$ graus e tribunais superiores). Muitos julgamentos de processos antigos estão ocorrendo para o cumprimento da referida meta, mas não se pode esquecer da qualidade desses julgamentos, pois de nada adiantará julgar rapidamente e de qualquer jeito os processos antigos, pois isso só gerará mais recursos e comprometimento à celeridade processual. Dado o atraso de alguns grandes tribunais da federação, apenas metade dos processos sujeitos à Meta 2 foram efetivamente julgados até o final de 2009.

Hoje, chegou-se à conclusão de que muitas das causas não poderiam ser julgadas individualmente, mas sim com base em julgamentos anteriores sobre a mesma matéria. Logo, cada vez mais, a Jurisprudência e os Precedentes passaram a ter um papel preponderante para a obtenção de um processo efetivo. Entretanto deve-se evitar as constantes mudanças de posições jurisprudenciais que estavam consolidadas, pois trazem insegurança jurídica, afetando a credibilidade de nossos Tribunais e causando enorme demora processual, pois as partes se veem obrigadas a recorrer sempre na esperança da mudança de um entendimento já pacificado, e as mudanças de orientação acabam gerando o ajuizamento de inúmeras Ações Rescisórias para desconstituir julgados que transitaram segundo a orientação pacificada e não mais vigente. 
Nos países da common law, temos a doutrina do stare decisis como o seu alicerce, já que uma decisão proferida pela corte de maior hierarquia deverá obrigatoriamente ser seguida pela própria corte e pelas cortes inferiores que estiverem sob a sua jurisdição. A aplicação do precedente é tão valorizada que, numa nova ação a ser julgada, discute-se mais sobre a existência, ou não, de analogia entre o caso julgado e o caso a ser decidido, do que sobre as virtudes ou defeitos dos precedentes.

Para fazer frente ao grande aumento no ajuizamento de ações judiciais, principalmente das ações repetitivas, foram propostas novas alterações na Constituição Federal e no Código de Processo Civil para aumentar a celeridade processual.

Sem dúvida, uma das maiores novidades das últimas reformas do Código de Processo Civil foi a inclusão do artigo 285-A pela Lei $\mathrm{n}^{\circ} 11.277 / 2006$, que prevê a resolução imediata dos processos se o juízo já houver proferido sentença de total improcedência em outros casos idênticos. Essa novidade legislativa de iniciativa do Poder Executivo, por meio do chamado "Pacote Republicano" de reformas do Código de Processo Civil, foi uma clara reação ao aumento dos Processos Repetitivos. Apesar do questionamento da Ordem dos Advogados do Brasil, o referido dispositivo não se mostra inconstitucional e deve ser aplicado de forma mais ampla e sem formalismos para que alcance os objetivos a que se propõe. Fato que preocupa é o entendimento de alguns tribunais que defendem a aplicação literal do referido dispositivo, anulando inutilmente sentenças em total afronta à simplificação dos julgamentos e à celeridade processual, que foram os alicerces que basearam a criação do artigo 285-A do CPC.

Outro instituto muito aguardado foi a Súmula Vinculante do Supremo Tribunal Federal. Apesar das abalizadas opiniões em contrário, tendo em vista a situação delicada da nossa assoberbada Justiça, não há como se concordar que as Súmulas Vinculantes inibiriam o livre convencimento dos Magistrados e engessariam a jurisprudência. Não faz sentido deixar o juiz de primeira instância livre para julgar de forma contrária aos entendimentos pacificados dos Tribunais Superiores e obrigar a parte a empreender grandes esforços e custos para chegar aos Tribunais Superiores e ter o seu caso julgado de acordo com o verbete sumulado. Mais justo, célere e eficaz é que o juiz de primeira instância se adapte ao referido entendimento pacificado e que tais esforços e 
custos sejam empregados pela outra parte para tentar alterar o entendimento pacificado. Uma preocupação importante é a de que o Supremo Tribunal Federal troque o julgamento de recursos pelo de Reclamações pelo descumprimento de Súmulas Vinculantes. Apesar de todo estardalhaço com as Súmulas Vinculantes é de se lamentar que até agora só existam vinte e sete e em matérias sem tanta projeção.

A Súmula Impeditiva de Recurso surgiu como alternativa menos radical que a súmula vinculante e também para prestigiar os entendimentos sumulados do Superior Tribunal de Justiça, que acabou sendo impedido de editar súmula vinculante. A Lei $\mathrm{n}^{\circ}$ 11.276, de 7 de fevereiro de 2006 introduziu o $\S 1^{\text {o }}$ ao artigo 518 do Código de Processo Civil que dispõe: “o juiz não receberá o recurso de apelação quando a sentença estiver em conformidade com súmula do Superior Tribunal de Justiça ou do Supremo Tribunal Federal". Talvez não se obtenham os resultados esperados, pois é de se esperar que em face da não admissão do recurso de apelação seja interposto agravo de instrumento por parte do Apelante. A Súmula Impeditiva de recurso pode muito bem ser compatibilizada com o julgamento liminar do mérito previsto no artigo 285-A do CPC.

A adoção de barreiras ao cabimento de recursos extraordinários não é nova. Ao longo da história, várias medidas foram adotadas para desafogar o Supremo Tribunal Federal. O papel das Cortes Supremas deve ser esse mesmo, de somente julgar as questões macros e de suma importância nacional, e não questões individuais e sem importância para o país como um todo. As Supremas Cortes não podem ser relegadas ao papel de uma terceira instância recursal. A Emenda Constitucional $n^{\circ} 45$ trouxe o requisito da existência da Repercussão Geral para o conhecimento dos Recursos Extraordinários. Isto é, só serão objeto de julgamento pelo STF as teses que transcendam as partes envolvidas e possam ter importância para toda a coletividade.

Para desafogar os Tribunais Superiores foi incluído em nosso sistema o julgamento por amostragem, tanto no Supremo Tribunal Federal (art. 543-B do CPC), quanto no Superior Tribunal de Justiça (art. 543-C do CPC). Por meio desses julgamentos, somente alguns recursos representativos de uma mesma tese seriam enviados aos Tribunais Superiores, enquanto os outros ficariam retidos nos Tribunais de origem. Quando do julgamento dos casos paradigmas, se os recursos estiverem em confronto com esse 
entendimento teriam o seu seguimento negado e se estivessem em consonância, a turma julgadora é chamada a reconsiderar a decisão. Realmente, não fazia sentido o sistema anterior, que permitia a subida aos Tribunais Superiores de milhares de processos idênticos, para que fossem julgados, individualmente, pelos Ministros. Os Tribunais Superiores devem julgar teses importantes e inéditas, sendo que os Tribunais locais e os juízes de primeiro grau devem adaptar esse entendimento para os processos judiciais. Os Tribunais Superiores não podem mais ser relegados a uma mera instância recursal.

Apesar de o julgamento por amostragem já ter gerado uma sensível diminuição na distribuição de feitos nos Tribunais Superiores, é de se esperar um aumento da sobrecarga dos tribunais locais com a separação de feitos por tese e a reconsideração de julgamentos, bem como, que a parte derrotada faça de tudo para levar a sua questão ao Tribunal Superior, frustrando a vantagem do dispositivo, que seria evitar que a questão fosse apreciada pelo STF ou pelo STJ.

Outra ferramenta importante para fazer frente aos recursos repetitivos foi a prevista no artigo 557 do CPC, com a autorização do julgamento monocrático de matérias já pacificadas. A grande maioria dos julgados dos nossos Tribunais Superiores já se dão de forma monocrática. O inconveniente do instituto é que a decisão é sujeita ao recurso de agravo, que deve ser julgado pelo órgão colegiado. Para se evitar o uso desmesurado do agravo, os Tribunais deveriam ser mais rígidos na aplicação das multas para os recursos manifestamente inadmissíveis ou infundados (art. 557, § $2^{\circ}$ ). Estudo recém lançado pela Faculdade de Direito da GV, no Rio de Janeiro, demonstra que o Tribunal de Justiça do Rio de Janeiro aplica o art. 557 em um grande número de decisões e que somente em 1/3 dos casos ocorre a interposição do agravo legal e estima-se que, em menos de 1\%, o órgão colegiado reforma a decisão monocrática. $\mathrm{O}$ estudo também aponta um dado interessante, mesmo no caso de ser realizado o julgamento monocrático e o colegiado (agravo), esse julgamento seria mais célere que o julgamento colegiado direto, pois o julgamento do agravo legal não necessita de formalidades, como a inclusão em pauta de julgamento. Esses dados se mostram interessantes, mas devem ser vistos com ressalvas, pois o Tribunal de Justiça do Rio de Janeiro possui muitas especificidades frente aos outros Tribunais da Federação, tais como, a gestão do valor das custas judiciais, pouco acervo de processo, fato que gera julgamentos muito céleres, etc. 
Sem dúvida, a tecnologia deve ser a grande aliada na abreviação da tramitação processual, pois o computador além de possibilitar a feitura e o armazenamento rápido, seguro e ordenado de decisões judiciais é uma grande arma para melhorar a gestão dos cartórios. De fato, com o auxílio da informática é possível separar-se processos por teses, por fases e agilizar a tramitação em bloco de feitos que se encontrem aguardando a mesma providência. Já a internet eliminou distâncias e hoje o processo virtual já é uma realidade e, em pouco tempo, é de se esperar que o processo de papel desapareça, com grande economia financeira, estrutural e ambiental.

A criação dos Juizados Especiais pode ser tida como um marco na Justiça Brasileira. Isso porque, é através deles que grande parcela da população tem acesso à Justiça, e é por eles que inúmeras demandas são (ou deveriam ser) resolvidas de forma célere e eficaz. Assim, é de grande importância o aprimoramento do ponto de contato da Justiça com a maioria dos cidadãos brasileiros que dela dependem para resolver seus conflitos. A imensidão de processos repetitivos tem inviabilizado os Juizados Especiais, sendo necessário que se implementem medidas de incentivo às soluções consensuais de controvérsias, visando à pacificação com a menor utilização do Poder Judiciário.

De fato, não são todos os litígios que deveriam ser obrigatoriamente levados à apreciação do Judiciário. A leitura precipitada do artigo $5^{\circ}, \mathrm{XXXV}$, da Constituição Federal pode levar à conclusão de que tudo pode e deve ser apreciado pelo Poder Judiciário, fechando as portas para outros meios de solução de controvérsia e agravando ainda mais a crise do Poder Judiciário e a celeridade almejada por todos. As partes devem ser orientadas sobre as diferentes alternativas para compor o conflito, sugerindo qual seria a saída mais adequada para o deslinde da questão. Dependendo do caso específico, pode ser sugerida a arbitragem, a mediação, a avaliação neutra de terceiro ou o processo judicial.

Como muitas vezes não se mostra possível a diminuição dos feitos em tramitação ou o aumento da estrutura judiciária para fazer frente à demanda crescente, é preciso que os escassos recursos sejam otimizados para que se possa aproveitar bem a estrutura disponível, para que se possa ter uma prestação mais célere e com o emprego de menos recursos Uma solução apresentada e que passou agora a ser mais discutida é o 
Gerenciamento do Processo, conhecido também como case management, que é uma tendência mundial e, em comarcas em que já foi aplicado, apresentou bons resultados.

O bom andamento do cartório mostra-se vital para a tramitação dos processos repetitivos, pois só com um cartório dinâmico e bem administrado é que se conseguirá a correta separação dos feitos a propiciar a tramitação em lotes de teses "idênticas", a aplicação do artigo 285-A do CPC e de tantas outras técnicas para o célere processamento dos feitos repetitivos. O processamento comum, "artesanal" e individualizado dessas causas sobrecarregará o cartório e será um grande óbice à celeridade processual.

A proliferação dos processos repetitivos indica que os mecanismos de resposta a demandas fundadas em direito difusos, coletivos ou individuais homogêneos (como, por exemplo, a ação civil pública e as ações coletivas) não têm sido capazes de proporcionar um tratamento efetivamente "molecular" das alegadas violações a direito. A abertura ilimitada para pleitos individuais de ações que deveriam ser claramente coletivas é algo a ser repensado. Não faz sentido o nosso sistema permitir a existência concomitante de quase 700 mil ações individuais e 721 ações coletivas para a discussão da mesma tese sobre o efeito dos planos econômicos nas cadernetas de poupança.

Também não se justificam as limitações ao cabimento de ações coletivas em face do Poder Público. Conforme visto, a grande maioria das ações que tramitam em nossa Justiça têm como parte, ao menos, um Ente Público e a partir do momento em que vai se proibindo o ajuizamento de Ações Coletivas em face dos referidos Entes Públicos, vai se obrigando o particular a ajuizar ações individuais idênticas, que certamente prejudicarão a efetividade processual. $\mathrm{O}$ incidente de coletivização das demandas individuais pode ser uma solução mais simples e funcional que as demandas coletivas, por se eliminarem várias questões processuais que atrasam a tramitação dos feitos coletivos. Essa possibilidade, já prevista no ordenamento alemão, deve fazer parte do anteprojeto do novo CPC e seria uma ferramenta muito importante para que se pudesse conciliar os processos repetitivos e a celeridade na tramitação processual. 
No final do trabalho, analisam-se alguns projetos de lei e ideias pinçadas em nossa doutrina, de alterações legislativas para a verificação de sua utilidade para equalizar a relação dos processos repetitivos com a celeridade que se busca na tramitação processual. É analisada a eventual previsão de limitação recursal nas causas de pequeno valor, a sucumbência recursal ou mesmo a diminuição da sucumbência no caso da parte não apelar, o fim do efeito suspensivo como regra nas apelações, o indeferimento da inicial quando o pedido contrariar súmula, a uniformização de jurisprudência e a impossibilidade de se conceder liminares em face de súmulas e os recursos per saltum e a avocatória.

Por fim, chega-se à conclusão de que ações de massa exigem medidas de massa, sendo necessário que se dê um tratamento especial para os processos repetitivos para não inviabilizar o processo como um todo. Novas técnicas vêm sendo criadas para fazer frente ao aumento dos processos repetitivos, entretanto elas ainda precisam ser aprimoradas e melhor aplicadas para que se tenha realmente um processo efetivo, que atinja os seus objetivos e seja célere. Os aplicadores do direito devem receber essas inovações com a mente aberta e levando sempre em conta que elas foram criadas para simplificar e abreviar a tramitação processual e não para criar atritos, formalismos e demora ao processo. 


\section{REFERÊNCIAS}

ABBUD, André de Albuquerque Cavalcanti. "O anteprojeto de lei sobre a repercussão geral dos recursos extraordinário", in Revista de Processo, n. 129, São Paulo, Revista dos Tribunais, 2005.

“A Repercussão Geral dos Recursos Extraordinário e o julgamento por amostragem no âmbito do Supremo Tribunal Federal (CPC, arts. 543-A e 543-B)", in As Novas Reformas do CPC e de outras normas processuais, coord. Maurício Giannico e Vítor José de Mello Monteiro, São Paulo, Saraiva, 2009.

Advocacia Geral da União. Disponível em <www.agu.gov.br> Acesso em 20/11/2009.

AGUIAR, Ruy Rosado. Propostas de Alteração do Sistema Recursal Civil, extraído do site $<w w w . c j f . j u s . b r>$.

ALLEMEERSCH, Benoît. "The Belgian perspective on case management in civil litigation" in Direito Processual Comparado, organizado por Ada Pellegrini Grinover e Petrônio Calmon Filho, Rio de Janeiro, Forense, 2007.

ANDREWS, Neil. O Moderno Processo Civil: formas judiciais e alternativas de resolução de conflitos na Inglaterra, orientação e revisão da tradução Teresa Arruda Alvim Wambier, São Paulo, Revista dos Tribunais, 2009.

ANDRIGHI, Fátima Nancy. "Mediação - Um Instrumento Judicial para a Paz social", in Revista do Advogado, São Paulo, Associação dos Advogados de São Paulo, 2006.

ARAGÃO, Egas Dirceu Moniz de. "Estatística Judiciária" in Revista Forense, n. 365, ano 99, Rio de Janeiro, Forense, 2003. 
ARAÚJO, Aline Modesto. "Modernização do Poder Judiciário através do processo virtual", in Revista da Escola Superior da magistratura de Pernambuco, v.13, n. 27, Recife, Emaspe, 2008.

ARAÚJO, José Henrique Mouta. "A verticalização das decisões do STF como instrumento de diminuição do tempo do processo: uma reengenharia necessária", in Revista de Processo, n. 164, São Paulo, Revista dos Tribunais, 2008.

"É cabível a desistência em caso de recurso especial repetitivo já afetado pelo STJ?", in Revista Brasileira de Direito Processual, ano 17, n. 66, Belo Horizonte, Fórum, 2009.

ARENHART, Sérgio Cruz. "A nova postura do relator no julgamento dos recursos”, in Revista de Processo, n. 103, São Paulo, Revista dos Tribunais, 2001.

ARRUDA ALVIM Netto, José Manoel de. "A EC n. 45 e o instituto da repercussão geral”, in Reforma do Judiciário: Primeiros ensaios críticos sobre a EC n. 45/2004, coordenação Teresa Arruda Alvim Wambier... [et al], São Paulo, Revista dos Tribunais, 2005.

ASSUMPÇÃO NEVES, Daniel. "Julgamento Liminar de improcedência e o recurso de apelação, in Revista de Processo, n. 152, São Paulo, Revista dos Tribunais, 2007.

Manual de Direito Processual Civil, São Paulo, Método, 2009.

ATHENIENSE, Alexandre. "A justiça brasileira e o processo eletrônico", in Revista Brasileira de Direito Processual, ano 17, n. 65, Belo Horizonte, Fórum, 2009.

BAHIA, Alexandre Gustavo Melo Franco. NUNES, Dierle José Coelho. "Por um renovado paradigma processual", in Revista IOB de Direito Civil e Processo Civil, n. 60, São Paulo, IOB, 2009. 
BAJONS, Ena-Marlis, "Civil Procedure for Austria revisited. An outline of recent Austrian civil procedure forms", in The reforms of civil procedure in comparative perspective, coord. Nicolò Trocker and Vicenzo Varano, Torino, Giappichelli, 2005.

BAPTISTA DA SILVA, Ovídio Araújo. "Tempo do Processo e Regulação da Sucumbência”, in Revista Dialética de Direito Processual, n. 7, São Paulo, 2003.

BARBOSA MOREIRA, José Carlos. Comentários ao Código de Processo Civil, $11^{\mathrm{a}}$ ed., v. V, Rio de Janeiro, Forense, 2003.

O Juízo de Admissibilidade no Sistema dos Recursos Civis, Rio de Janeiro, 1968.

. "A Constituição e as provas ilicitamente obtidas", in Temas de direito processual, 6 ${ }^{\text {a }}$ série, São Paulo, Saraiva, 1977.

. "O Futuro da Justiça: alguns mitos", in Revista da Escola Paulista da Magistratura, v. 2, n. 1, 2001.

"A duração dos processos: Alguns dados comparativos", in Revista Síntese de Direito Civil e Processual Civil, n. 29, 2004.

. "A Emenda Constitucional 45/2004 e o processo", in Revista Dialética de Direito Processual, n. 33, São Paulo, Dialética, 2005.

. "Efetividade do processo e técnica processual", in Revista de Processo, n. 77, São Paulo, Revista dos Tribunais, 1995.

. "Súmula Vinculante e duração dos processos", in Advocacia Dinâmica: Seleções Jurídicas, agosto de 2004.

"Súmula, jurisprudência, precedente: uma escalada e seus riscos", in Revista Dialética de Direito Processual, n. 27, São Paulo, Dialética, 2005. 
. "O problema da duração dos processos: premissas para uma discussão séria", in Temas de direito processual civil, $9^{\circ}$ série, São Paulo, Saraiva, 2007.

BARBOSA, Rui. Oração aos Moços. São Paulo, Papagaio, 2003.

BARNET, Andreu Estela. "El proceso formativo em la gestión por competencias para jueces: la Escuela Judicial de España”, in Revista CEJ, n. 42, Brasilia, 2008.

BARROS, Humberto Gomes de. "Superior Tribunal de Justiça versus Segurança Jurídica", in Revista do Advogado, n. 103, São Paulo, AASP, 2009.

BECHO, Renato Lopes. "Efeitos do ajuizamento tardio das Execuções Fiscais", in Revista Dialética de Direito Tributário, n. 170, São Paulo, Dialética, 2009.

BEDAQUE, José Roberto dos Santos. "Nulidade processual e instrumentalidade do processo", in Revista de Processo, n. 60, São Paulo, Revista dos Tribunais, 1990.

Efetividade do Processo e Técnica Processual, São Paulo, Malheiros, 2006.

e CARMONA, Carlos Alberto. "A posição do juiz: tendências atuais”, in Revista de Processo, n. 96, São Paulo, Revista dos Tribunais, 1999.

BENETI, Sidnei Agostinho. "Assunção de Competência e fast-track recursal" in Revista de Processo, n. 171, São Paulo, Revista dos Tribunais, 2009.

. “A Interpretação das Leis de Simplificação do Código de Processo Civill,, Revista do Advogado, n. 46, São Paulo, AASP, 1995.

- "Doutrina de precedentes e Organização Judiciária", in Processo e Constituição: Estudos em Homenagem ao Professor José Carlos Barbosa Moreira (Coordenação Luiz Fux, Nelson Nery Júnior e Teresa Arruda Alvim Wambier). São Paulo, Revista dos Tribunais, 2006. 
. "Resolução Alternativa de Conflitos (ADR) e Constitucionalidade", in Revista do Instituto dos Advogados de São Paulo, n. 9, São Paulo, Revista dos Tribunais, 2002.

BENUCCI, Renato Luís. A tecnologia aplicada ao Processo Judicial, Campinas, Millennium, 2006.

BERIZONCE, Roberto Omar. "Problemas Fundamentales del Sistema de Justicia Civil en Iberoamérica y propuestas de solución", in Direito Processual Comparado, organizado por Ada Pellegrini Grinover e Petrônio Calmon Filho, Rio de Janeiro, Forense, 2007, p. 706).

BIELSA, Rafael A., BRENNA, Ramón G. Reforma de la Justicia y Nuevas Tecnologías, Buenos Aires, Ad Hoc, 1996.

BONDIOLI, Luis Guilherme Aidar. O Novo CPC - a terceira etapa da reforma. São Paulo, Saraiva, 2006.

. "O julgamento liminar de improcedência da demanda da óptica do réu (art. 285A do CPC)", in Revista Jurídica, n. 367, Porto Alegre, Notadez, 2008.

“ “A Nova Técnica de julgamento dos Recursos Extraordinário e Especial Repetitivos", 2009, inédito.

BONÍCIO, Marcelo José Magalhães. “As Reformas do CPC e a necessidade do Prévio Esgotamento das Instâncias para fins de interposição de Recurso Especial e Extraordinário, in Revista Dialética de Direito Processual, n. 68, São Paulo, Dialética, 2008.

BOTTINI, Pierpaolo Cruz. "Contornos da reforma contemporânea do processo civil", in Revista de Processo, n. 143, São Paulo, Revista dos Tribunais, 2007.

BRESOLIN, Umberto Bara. "Considerações sobre o artigo 285-A do Código de Processo Civil", in Reflexões sobre a Reforma do Código de processo civil: estudos em homenagem 
a Ada Pellegrini Grinover, Cândido R. Dinamarco e Kazuo Watanabe, coord. Carlos Alberto Carmona, São Paulo, Atlas, 2007.

BRUSCHI, Gilberto Gomes. "Casos Idênticos e os Requisitos para a aplicação do art. 285A do CPC", in Revista Dialética de Direito Processual, n. 78, São Paulo, Dialética, 2009.

CABRAL, Antonio do Passo. "O novo procedimento-modelo (Musterverfahren) alemão: uma alternativa às ações coletivas”, in Revista de Processo, n. 147, São Paulo, Revista dos Tribunais, 2007.

CALMON FILHO, Petrônio. "A Informatização do Processo Judicial Brasileiro", in Direito Processual Comparado, organizado por Ada Pellegrini Grinover e Petrônio Calmon Filho, Rio de Janeiro, Forense, 2007

Comentários à Lei de Informatização do Processo Judicial: Lei $n^{\circ} 11.419$, de 19 de dezembro de 2006, Rio de Janeiro, Forense, 2007.

CALMON DE PASSOS, José Joaquim. "Considerações de um troglodita sobre o processo eletrônico", in Processo Civil - Notas Tendências - Homenagem ao Professor Humberto Theodoro Júnior, coord. Fernando Gonzaga Jayme, Juliana Cordeiro de Faria e Maíra Terra Lauar, Belo Horizonte, Del Rey, 2008.

CAMBI, Eduardo. "Julgamento prima facie (imediato) pela técnica do artigo 285-A do CPC", in Direito e Processo: Estudos em Homenagem ao Desembargador Norberto Ungaretti, Coord. Pedro Manoel Abreu e Pedro Miranda de Oliveira, Florianópolis, Conceito Editorial, 2007.

CAMPO, Hélio Marcio. “A crise do Supremo Tribunal Federal Brasileiro e a proposta de um novo filtro para o Recurso Extraordinário: Repercussão Geral das Questões Constitucionais", in Estudios Iberoamericanos de derecho procesal - Libro Homenaje a José Gabriel Sarmiento Núñez, Bogotá, Legis, 2005 (Compilador Carlos J. Sarmiento Sosa). 
CAPONI, Remo. "Modelli europei di tutela collettiva nel processo civile: esperienze tedesca e italiana a confronto", in Rivista Trimestrale di Diritto e Procedura Civile, anno LXI, n. 4, Milano, Giuffrè, 2007.

CARMONA, Carlos Alberto. "O sistema recursal brasileiro: breve análise crítica", in Aspectos polêmicos e atuais dos recursos, São Paulo, Revista dos Tribunais, 2000 (coordenação de Eduardo Pellegrini de Arruda Alvim, Teresa Arruda Alvim Wambier e Nelson Nery Junior).

"Quinze anos de reformas no Código de Processo Civil", in Reflexões sobre a Reforma do Código de processo civil: estudos em homenagem a Ada Pellegrini Grinover, Cândido R. Dinamarco e Kazuo Watanabe, coord. Carlos Alberto Carmona, São Paulo, Atlas, 2007.

CARNEIRO, Athos Gusmão. Cumprimento da Sentença Civil, Rio de Janeiro, Forense, 2007. . "Primeiras observações sobre a lei dos recursos repetitivos no STJ", in Revista de Processo, n. 160, São Paulo, Revista dos Tribunais, 2008.

CARNEVALI, Davide. "La violazione della ragionevole durata del processo: Alcuni dati sull'applicazione della 'Legge Pinto'”, in Giusto Processo?, a cura di Carlo Guarnieri e Francesca Zannotti, Milano, Cedam, 2006.

CARPI, Frederico. "Le riforme del processo civile in Itália verso il XXI secolo", in Rivista Trimestrale di Diritto e Procedura Civile, ano LIV, n. 1, Milano, Giuffrè, 2000.

CARREIRA ALVIM, José Eduardo. "Recurso Per Saltum - Sugestão para a Justiça do Terceiro Milênio" in Revista do Instituto dos Advogados de São Paulo, ano V, n. 10, julho/dezembro 2002, São Paulo, Revista dos Tribunais.

CHASE, Oscar G., "Reflections on civil procedure reform in the United States: What has been learned? What has been accomplished?", in The reforms of civil procedure in 
comparative perspective, coord. Nicolò Trocker and Vicenzo Varano, Torino, Giappichelli, 2005.

CHIARLONI, Sergio. "Efficacia Del precedente giudiziario e tipologia dei contrasti di giurisprudenza", in Rivista Trimestrale di Diritto e Procedura Civile, anno XLIII, n. 1, Milano, Giuffrè, 1989.

. "Il nuovo art. 111 Cost. e il processo civile", in Rivista di Diritto Processuale, anno LV, n. 4, Padova, Cedam, 2000.

- "Um mito rivisitato: Note comparative sull'autorità del precedente giurisprudenziale", in Rivista di Diritto Processuale, anno LVI, n. 3, Padova, Cedam, 2001.

CIMARDI, Cláudia A. "Notas sobre o art. 285-A do CPC (sentença liminar de improcedência)", in Os Poderes do Juiz e o Controle das decisões judiciais - Estudos em Homenagem à professora Teresa Arruda Alvim Wambier, coord. José Miguel Garcia Medina et. al, São Paulo, Revista dos Tribunais, 2008.

COLE, Charles D. "Stare Decisis na Cultura Jurídica dos Estados Unidos. O Sistema de Precedente vinculado do Common Law", in Revista dos Tribunais, n. 752, São Paulo, Revista dos Tribunais, 1998.

Conselho da Justiça Federal. Disponível em <www.cjf.jus.br>.

Conselho Nacional de Justiça. Disponível em <www.cnj.jus.br > Acesso em 04/01/2010.

Consultor Jurídico. Disponível em <www.conjur.com.br> Acessos em 26/10/2009, $13 / 06 / 2009$ e $30 / 11 / 2009$.

COUTINHO, Jacinto Nelson de Miranda. "Discurso proferido na Mesa de Redonda de Abertura", in Encontro Brasil - Espanha: A Reforma Processual, coord. Cláudio Lembo, São Paulo, Minha Editora, Brasília, Instituto Tancredo Neves, 2006. 
CRETELla NETTO, José. Fundamentos Principiológicos do Processo Civil, Rio de Janeiro, Forense, 2002.

CUNHA, Leonardo José Carneiro. "Primeiras Impressões sobre o art. 285-A do CPC (Julgamento Imediato de Processos Repetitivos: uma racionalização para as demandas de massa)", in Revista Dialética de Direito Processual, n. 39, São Paulo, Dialética, 2006.

CUNHA, Sérgio Sérvulo da. "A arcaica Súmula Vinculante", in Reforma do Judiciário, coord. Sérgio Rabello Tamm Renault e Pierpaolo Bottini, São Paulo, Saraiva, 2005.

DIAS, Luciana Drimel. "Dossiê Itália: a grave e profunda crise de duração dos processos/alerta e subsídio", in Genesis - Revista de Direito Processual Civil, n. 26, Curitiba, Editora Genesis, 2002.

DIAS, Rogério A. Correia. "A razoável duração do processo: idéias para sua concreção", in As grandes transformações do Processo Civil Brasileiro: Homenagem ao Professor Kazuo Watanabe, coord. Carlos Alberto Salles, São Paulo, Quartier Latin, 2009.

DIDIER JÚNIOR, Fredie e CUNHA, Leonardo José Carneiro. Curso de Direito Processual Civil, v. 3, 3. ed., Salvador, JusPodivm, 2007.

“Tópicos sobre a última reforma processual (dezembro de 2006) (Parte 1)”, in Revista de Processo, n. 147, São Paulo, Revista dos Tribunais, 2007.

DINAMARCO, Cândido Rangel. A Reforma da Reforma. São Paulo, Malheiros, 2002.

. "Decisões Vinculantes", in Revista de Processo, n. 100, São Paulo, Revista dos Tribunais, 2000.

. "Súmulas Vinculantes", in Revista Forense, v. 347, Rio de Janeiro, Forense, 1999. 
. A Instrumentalidade do Processo, 10ª ed., São Paulo. Malheiros 2002.

. Instituições de Direito Processual Civil. São Paulo, Malheiros, 2009.

. "O Processo Civil na Reforma Constitucional do Poder Judiciário”, in Reforma do Judiciário, coord. Sérgio Rabello Tamm Renault e Pierpaolo Bottini, São Paulo, Saraiva, 2005.

Vocabulário do Processo Civil, Malheiros, São Paulo, 2009.

DINAMARCO, Pedro da Silva. Ação Civil Pública, São Paulo, Saraiva, 2001.

DUARTE, Ricardo Quass. O Tempo Inimigo no Processo Civil Brasileiro, São Paulo, LTr, 2009.

EPSTEIN, Judd A. "The quite revolution in Australia - The changing role of the judge in civil proceedings" in The reforms of civil procedure in comparative perspective, coord. Nicolò Trocker and Vicenzo Varano, Torino, Giappichelli, 2005.

FAIM FILHO, Eurípedes Gomes. "Execuções Fiscais de pequeno valor e o respeito ao Erário”, in Revista Direito Tributário Atual, n. 23, São Paulo, Dialética, 2009.

FARIA, José Eduardo. "A crise do judiciário no Brasil: notas para discussão", in Jurisdição e Direitos Fundamentais, coord. Ingo Wolfgang Sarlet, vol. 1, tomo 1, Porto Alegre, Livraria do Advogado / AJURIS, 2005.

FARIA, Paulo Ramos de. Regime Processual Experimental - A gestão processual no processo declarativo comum experimental, Porto, Cejur, 2009.

FERRAND, Frédérique. "The Respective role of the judge and the parties in the preparation of the case in France", in The reforms of civil procedure in comparative perspective, coord. Nicolò Trocker and Vicenzo Varano, Torino, Giappichelli, 2005 
FERRAZ, Leslie Shérida. Decisão Monocrática e Agravo Interno: Celeridade ou entrave processual? A Justiça no Estado do Rio de Janeiro, Rio de Janeiro, FGV Direito Rio, 2009.

."A conciliação nos Juizados Especiais Cíveis: uma análise empírica", in As grandes transformações do Processo Civil Brasileiro: Homenagem ao Professor Kazuo Watanabe, coord. Carlos Alberto Salles, São Paulo, Quartier Latin, 2009.

FERREIRA, Manuel Amâncio. Manual dos Recursos em Processo Civil, $5^{\mathrm{a}}$ ed., Coimbra, Almedina, 2004.

FREITAS, Elizabeth Cristina Campos Martins de. "A aplicação restritiva da súmula vinculante em prol da efetividade do direito", in Revista de Processo, n. 116, São Paulo, Revista dos Tribunais, 2004.

FREITAS, José Lebre. "Notas sobre o regime processual experimental", in Novas Exigências do Processo Civil, Coimbra Editora, 2007.

. "Experiência-Piloto de um novo processo civil", in Novas Exigências do Processo Civil, Coimbra Editora, 2007.

FREITAS, Vladimir Passos de. e Dario Almeida Passos de. (coords.) Direito $e$ Administração da Justiça, Curitiba, Juruá, 2006.

GAJARDONI, Fernando da Fonseca. "Técnica de Aceleração do Processo. São Paulo, Lemos \& Cruz, 2003.

"O princípio constitucional da tutela jurisdicional sem dilações indevidas e o julgamento antecipadíssimo da lide (artigo 285-A do CPC)", in As grandes transformações do Processo Civil Brasileiro: Homenagem ao Professor Kazuo Watanabe, coord. Carlos Alberto Salles, São Paulo, Quartier Latin, 2009. 
ROMANO, Michel Betenjane e LUCHIARI, Valéria Ferioli Lagrasta. "O Gerenciamento do processo", in Mediação e Gerenciamento do Processo - Revolução na prestação Jurisdicional, coordenação de Ada Pellegrini Grinover, Kazuo Watanabe e Caetano Lagrasta Neto, São Paulo, Atlas, 2007.

GÁlVEZ, Juan Monroy. PALÁCIOS, Juan José Monroy. "Las relaciones entre Jueces, Partes y Abogados en el Proceso Civil Peruano", in Proceso Civil: hacia una nueva Justicia Civil, coord. Andrés de la Oliva Santos e Diego Iván Palomo Vélez, Santiago, Editorial Jurídica de Chile, 2007.

GERALDES, Antônio Santos Abrantes. "Processo Especial Experimental de litigância de massas", in Novas Exigências do Processo Civil, Coimbra Editora, 2007.

GERHARDT, Michael J. The Power of Precedent, New York, Oxford, 2008.

GIMENEZ, Ignacio Díez-Picazo. "The Principal innovations of Spain's recent civil procedure reform", in The reforms of civil procedure in comparative perspective, coord. Nicolò Trocker and Vicenzo Varano, Torino, Giappichelli, 2005.

GIORGETTI, Alessandro. VALLEFUOCO, Valerio. Il contenzioso di massa in Italia, in Europa e nel mondo - Profili di comparazione in tema di Azioni di Classe Ed Azioni di Gruppo, Milano, Giuffrè, 2008.

GÓES, Gisele Santos Fernandes. "Razoável duração do processo", in Reforma do Judiciário: Primeiros ensaios críticos sobre a EC n. 45/2004, coordenação Teresa Arruda Alvim Wambier... [et al], São Paulo, Revista dos Tribunais, 2005.

GOMES, Conceição. O tempo dos Tribunais: Um estudo sobre a morosidade da justiça, Coimbra Editora, 2003.

GOMES, Marcus Lívio. "Perspectivas para a execução fiscal no Brasil: execução físcal judicial x execução fiscal administrativa - qual o melhor caminho?", in Revista CEJ, ano XIII, n. 45, Brasília, 2009. 
GOUVEIA, Mariana França. "A acção especial de litigância de massa”, in Novas Exigências do Processo Civil, Coimbra Editora, 2007.

Regime Processual Experimental Anotado, Coimbra, Almedina, 2006.

GRECO, Leonardo. "Novas Súmulas do STF e alguns reflexos sobre o Mandado de Segurança", in Revista Dialética de Direito Processual, n. 10, São Paulo, Dialética, 2004.

GRINOVER, Ada Pelegrini. Os princípios constitucionais e o código de processo civil. São Paulo, José Bushatsky, 1975.

. “A Reforma do Poder Judiciário. Contribuição do Instituto Brasileiro de Direito Processual - IBDP”, in Revista do Advogado, São Paulo, AASP, 2004.

. "O tratamento dos processos repetitivos", in Processo Civil - Notas Tendências

- Homenagem ao Professor Humberto Theodoro Júnior, coord. Fernando Gonzaga Jayme, Juliana Cordeiro de Faria e Maíra Terra Lauar, Belo Horizonte, Del Rey, 2008.

. "Discurso proferido na Mesa de Redonda de Abertura", in Encontro Brasil -

Espanha: A Reforma Processual, coord. Cláudio Lembo, São Paulo, Minha Editora, Brasília, Instituto Tancredo Neves, 2006.

. "A 'class action' Brasileira", in Livro de Estudos Jurídicos, coord. James Tubenchlak e Ricardo Silva de Bustamante, v. 2, Rio de Janeiro, Instituto de Estudos Jurídicos, 1991.

. "Os fundamento da Justiça Conciliativa", in Mediação e Gerenciamento do Processo - Revolução na prestação Jurisdicional, coordenação de Ada Pellegrini Grinover, Kazuo Watanabe e Caetano Lagrasta Neto, São Paulo, Atlas, 2007. 
, WATANABE, Kazuo e LAGASTRA NETO, Caetano. Mediação $e$ Gerenciamento do Processo - Revolução na prestação Jurisdicional, São Paulo, Atlas, 2007.

HOFFMAN, Paulo. Razoável duração do processo. São Paulo, Quartier Latin, 2006.

Instituto Brasileiro de Direito Processual. Disponível em <www.direitoprocessual.org.br> Acesso em 04/01/2010.

ISSACHAROFF, Samuel. Civil Procedure, New York, Foundation Press, 2005.

JORGE, Nuno de Lemos. "Notas sobre o regime processual experimental", in Novas Exigências do Processo Civil, Coimbra Editora, 2007.

Jornal do Commercio, edição de 10/12/2009.

Jornal Folha de São Paulo, edição de 24/11/2009.

Jornal O Estado de São Paulo, edições de 12/03/2009, 05/08/2009 e 03/12/2009, p. A11.

Jornal Tribuna do Direito, edição de dezembro de 2009, p 12.

Jornal Valor Econômico, edições de 14/11/2006, 14/12/2006, 26/12/2007, 29/12/2008, 13/10/2009, 27/10/2009, 17/11/2009 e 10/12/2009, p. E1.

LEAL, Victor Nunes. "Passado e futuro da Súmula do Supremo Tribunal Federal", in Revista de Direito Administrativo, n. 145, Rio de janeiro, Fundação Getúlio Vargas, 1981.

LEONEL, Ricardo de Barros. Manual do Processo Coletivo, São Paulo, Revista dos Tribunais, 2002.

Reformas recentes do Processo Civil - comentário sistemático, São Paulo, Método, 2007. 
. "A Eficácia imediata da sentença e as reformas do Código de Processo Civil: um aspecto da caminhada para a efetividade da tutela jurisdicional", in Revista de Processo, n. 119, São Paulo, Revista dos Tribunais, 2005.

LEVY, Daniel. "O dano do processo lento", in Revista Trimestral de Direito Civil, ano 9, v. 36, Rio de Janeiro, Padma, 2008.

LOPES, João Batista. "Efetividade do Processo e Reforma do Código de Processo Civil: Como explicar o paradoxo processo moderno - Justiça morosa?”, in Revista de Processo, n. 105, São Paulo, Revista dos Tribunais, 2002.

LORENCINI, Marco Antonio Garcia Lopes. "A contribuição dos meios alternativos para a solução das controvérsias", in As grandes transformações do Processo Civil Brasileiro: Homenagem ao Professor Kazuo Watanabe, coord. Carlos Alberto Salles, São Paulo, Quartier Latin, 2009.

(coordenador) Estudo sobre Execuções Fiscais no Brasil, promovido pelo Ministério da Justiça - Secretária de Reforma do Judiciário em parceria com o Centro Brasileiro de Estudos e Pesquisas Judiciais - CEBEPEJ, Brasília, 2007.

LUISO, Francesco Paolo. "Prime osservazioni sul disegno Mastella", disponível no site $<$ www.judicium.it> Acesso em 26/04/2007.

__ "La conciliazione nel quadro della tutela dei diritti", in Studi di Diritto Processuale Civile in Onore di Giuseppe Tarzia, Tomo III, Milano, Giuffrè, 2005.

MACIEL, Adhemar Ferreira. "Considerações sobre as causas do emperramento do judiciário”, in Revista de Processo, n. 97, São Paulo, Revista dos Tribunais, 2000.

"Restrições à Admissibilidade de Recursos na Suprema Corte dos Estados Unidos e no Supremo Tribunal Federal do Brasil", in Meios de Impugnação ao julgado civil: 
Estudos em Homenagem a José Carlos Barbosa Moreira, Coord. Adroaldo Furtado Fabrício, Rio de Janeiro, Forense, 2007.

_. “Avocatória: Violação do 'Juiz Natural' ou uma exigência dos novos tempos?” in As garantias do cidadão na Justiça, coord. Sálvio Figueiredo Teixeira, São Paulo, Saraiva, 1993.

MADALENA, Pedro. "Magistratura: produtividade controlada em processo virtual", in Revista da Ajuris, n. 111, Porto Alegre, 2008.

MANCUSO, Rodolfo de Camargo. “A Realidade Judiciária Brasileira e os Tribunais da Federação - STF e STJ; Inevitabilidade de Elementos de Contenção dos Recursos a eles Dirigidos", in Processo e Constituição: Estudos em Homenagem ao Professor José Carlos Barbosa Moreira (Coordenação Luiz Fux, Nelson Nery Júnior e Teresa Arruda Alvim Wambier). São Paulo, Revista dos Tribunais, 2006.

— "O plano piloto de conciliação em segundo grau de jurisdição, do Egrégio Tribunal de Justiça de São Paulo, e sua possível aplicação aos feitos de interesse da Fazenda Pública", in Estudos de Direito Processual Civil - Homenagem ao Professor Egas Dirceu Moniz de Aragão, São Paulo, Revista dos Tribunais 2005.

Divergência Jurisprudencial e Súmula Vinculante. São Paulo, Revista dos Tribunais, 1999.

_ _Súmula Vinculante e a EC n. 45/2004", in Reforma do Judiciário: Primeiros ensaios críticos sobre a EC n. 45/2004, coordenação Teresa Arruda Alvim Wambier... [et al], São Paulo, Revista dos Tribunais, 2005.

_ _ "Contribuição esperada do Ministério Público e da Defensoria Pública na prevenção da atomização judicial dos mega-conflitos", in Revista de Processo, n. 164, São Paulo, Revista dos Tribunais, 2008. 
“A resolução dos conflitos e a função judicial no contemporâneo Estado de Direito (nota introdutória), in Revista dos Tribunais, n. 888, São Paulo, Revista dos Tribunais, 2009.

MARCATO, Antônio Carlos. Crise da Justiça e influência dos Precedentes Judiciais no Direito Processual Civil Brasileiro, Tese apresentada para o concurso de Professor Titular de Direito Processual Civil do Departamento de Direito Processual da Faculdade de Direito da Universidade de São Paulo, inédita, 2008.

MARINONI, Luiz Guilherme, "Ações Repetitivas e julgamento liminar", in Direito $e$ Processo: Estudos em Homenagem ao Desembargador Norberto Ungaretti, Coord. Pedro Manoel Abreu e Pedro Miranda de Oliveira, Florianópolis, Conceito Editorial, 2007.

. "Aproximação crítica entre as jurisdições de civil law e de common law e a necessidade de respeito aos precedentes no Brasil", in Revista de Processo, n. 172, São Paulo, Revista dos Tribunais, 2009.

MEDINA, Diego Eduardo López. El derecho de los jueces: obligatoriedad del precedente constitucional, análisis de sentencias y líneas jurisprudenciales y teoría del derecho judicial, $2^{\mathrm{a}}$ ed., Bogotá, Legis, 2006.

MEDINA, José Miguel Garcia. WAMBIER, Luiz Rodrigues. WAMBIER, Teresa Arruda Alvim. "A Súmula vinculante, vista como legítimo para diminuir a sobrecarga de trabalho dos tribunais brasileiros", in Revista do Advogado, n. 92, São Paulo, Associação dos Advogados de São Paulo, 2007.

MELO, Gustavo de Medeiros. "Julgamento liminar de improcedência. Uma leitura sistemática da Lei 11.277/2006", in Revista de Processo, n. 165, São Paulo, Revista dos Tribunais, 2008.

MENDES, Aluisio Gonçalves de Castro. "Do individual ao coletivo: os caminhos do direito processual brasileiro", in Revista de Processo, n. 165, São Paulo, Revista dos Tribunais, 2008. 
MENDES, Gilmar Ferreira. PFLUG, Samantha Meyer. "Passado e presente da Súmula Vinculante: Considerações à Luz da Emenda Constitucional n. 45/2004”, in Reforma do Judiciário, coord. Sérgio Rabello Tamm Renault e Pierpaolo Bottini, São Paulo, Saraiva, 2005.

MENDONÇA, Luís Correia de. "Processo Civil líquido e garantias (o regime processual experimental português), in Revista de Processo, n. 170, São Paulo, Revista dos Tribunais, 2009.

MESQUITA, José Ignacio Botelho de. "A crise do Judiciário e o Processo", in Revista da Escola Paulista da Magistratura, v. 2, n. 1, p. 85. São Paulo: 2001.

. "A Súmula da Jurisprudência Predominante no Supremo Tribunal Federal”, in Teses, Estudos e Pareceres de Processo Civil, v. 2, São Paulo, Revista dos Tribunais, 2005.

"Uniformização da Jurisprudência (esboço de substitutivo ao projeto de lei 3.804/93)", in Teses, Estudos e Pareceres de Processo Civil, v. 2, São Paulo, Revista dos Tribunais, 2005.

"As novas tendências do direito processual: uma contribuição para o seu reexame", in Teses, Estudos e Pareceres de Processo Civil, v. 1, São Paulo, Revista dos Tribunais, 2005.

MICHAVILLA, José María. "Discurso proferido na Mesa de Redonda de Abertura", in Encontro Brasil - Espanha: A Reforma Processual, coord. Cláudio Lembo, São Paulo, Minha Editora, Brasília, Instituto Tancredo Neves, 2006.

Migalhas. Disponível em <www.migalhas.com.br> Acesso em 21/12/2009.

MIRANDA, Tássia Baia. "Stare decisis e a aplicação do precedente no sistema norteamericano", in Revista da Ajuris, n. 106, Porto Alegre, 2007. 
MITIDIERO, Daniel. "A multifuncionalidade do direito fundamental ao contraditório e a improcedência liminar (art. 285-A): resposta à crítica de José Tesheiner", in Revista de Processo, n. 144, São Paulo, Revista dos Tribunais, 2007.

MOLLICA, Rogerio. "O excesso de formalismo como obstáculo à celeridade processual", in Bases Científicas para um renovado Direito Processual, coord. Athos Gusmão Carneiro e Petrônio Calmon, Brasília, Instituto Brasileiro de Direito Processual, 2008.

MORAES, Alexandre. "O Papel das Cortes Superiores. Harmonização do Direito na Globalização", in Encontro Brasil - Espanha: A Reforma Processual, coord. Cláudio Lembo, São Paulo, Minha Editora, Brasília, Instituto Tancredo Neves, 2006.

NALINI, José Renato. "Duração razoável do processo e a dignidade da pessoa humana", in Tratado Luso-Brasileiro da Dignidade Humana, coord. Jorge Miranda e Marco Antonio Marques da Silva, São Paulo, Quartier Latin, 2008.

NEGRÃO, Theotonio e GOUVÊA, José Roberto Ferreira. Código de Processo Civil e Legislação Processual em Vigor. 39a ed., São Paulo, Saraiva, 2007.

NERY JÚNIOR, Nelson. Princípios Fundamentais - Teoria Geral dos Recursos, $4^{\mathrm{a}}$ ed., São Paulo, Revista dos Tribunais, 1997.

NETTO, Domingos Franciulli. “A reforma do poder judiciário. Controle externo. Súmula vinculante", in Reforma do Judiciário: Primeiros ensaios críticos sobre a EC n. 45/2004, coordenação Teresa Arruda Alvim Wambier... [et al], São Paulo, Revista dos Tribunais, 2005 .

OLIVEIRA, Pedro Miranda de. "Decisão-sentença nos tribunais: uma proposta de lege ferenda”, in Revista Brasileira de Direito Processual, n. 65, Belo Horizonte, Fórum, 2009.

OLIVEIRA, Robson Carlos de. "Breves Reflexões sobre o Princípio Constitucional da Razoável Duração do Processo tendo como Paradigma os Juizados Especiais Federais: 
Como a Frutífera Experiência desse Sistema pode ser Aproveitada pelo Processo Civil Comum", in Processo e Constituição: Estudos em Homenagem ao Professor José Carlos Barbosa Moreira (Coordenação Luiz Fux, Nelson Nery Júnior e Teresa Arruda Alvim Wambier). São Paulo, Revista dos Tribunais, 2006.

OTEIZA, Eduardo. "El Problema de la Uniformidad de la Jurisprudência em América Latina”, in Revista de Processo, n. 136, São Paulo, Revista dos Tribunais, 2006.

PARENTE, Eduardo de Albuquerque. Jurisprudência da Divergência à Uniformização. São Paulo, Atlas, 2006.

. "A Súmula impeditiva de recursos e o sistema de precedentes", in Reflexões sobre a Reforma do Código de processo civil: estudos em homenagem a Ada Pellegrini Grinover, Cândido R. Dinamarco e Kazuo Watanabe, coord. Carlos Alberto Carmona, São Paulo, Atlas, 2007.

PASSONI, Marcos Paulo. "Sobre o cabimento da ação rescisória com fundamento em violação à literal proposição de súmula vinculante", in Revista de Processo, n. 171, São Paulo, Revista dos Tribunais, 2009.

PEREIRA, Ademar. "Discurso proferido na Mesa de Redonda de Abertura", in Encontro Brasil - Espanha: A Reforma Processual, coord. Cláudio Lembo, São Paulo, Minha Editora, Brasília, Instituto Tancredo Neves, 2006.

PERROT, Roger. "O processo civil francês na véspera do século XXI", tradução de José Carlos Barbosa Moreira, in Revista de Processo, n. 91, São Paulo, Revista dos Tribunais, 1998.

PUOLI, José Carlos Baptista. Os Poderes do Juiz e as Reformas do Processo Civil, São Paulo, Juarez de Oliveira, 2002.

Procuradoria da Fazenda Nacional. Disponível em <www.pgfn.fazenda.gov.br> Acesso em 20/11/2009. 
QUIRINO, Hamilton. "Importância da mediação prévia obrigatória”, extraído do site <www. caesp.org.br> Acesso em 08/01/2010.

RICCI, Gian Franco. La Riforma del Processo Civile - Legge 18 giugno 2009, n. 69, Torino, G. Giappichelli, 2009.

RODRIGUES, Francisco César Pinheiro. "Propostas para nova sistemática para recursos. Efeito da sucumbência, in Revista CEJ, n. 13, Brasília, 2001.

- "Meta de Nivelamento 2, do CNJ - Limpar prateleiras", disponível em $<$ www.amb.com.br> Acesso em 05/11/2009.

RODRIGUES, Walter Piva. "O Princípio da Colegialidade das Decisões dos Tribunais", in Revista Dialética de Direito Processual Civil, n. 1, 2003.

Coisa Julgada Tributária, São Paulo, Quartier Latin, 2008.

RUTGERS, G. Robert e Jacobien W., "Reform of the code of civil procedure in the Netherlands", in The reforms of civil procedure in comparative perspective, coord. Nicolò Trocker and Vicenzo Varano, Torino, Giappichelli, 2005.

SÁ, Djanira Maria Radamés de. e PIMENTA, Haroldo. "Reflexões Iniciais sobre o art. 285-A do Código de Processo Civil", ", in Revista de Processo, n. 136, São Paulo, Revista dos Tribunais, 2006.

SADEK, Maria Tereza. "Justiça em números: novos ângulos”, disponível em <www.migalhas.com.br> Acesso em 30/10/2009.

. "Juizados Especiais: um novo paradigma", in As grandes transformações do Processo Civil Brasileiro: Homenagem ao Professor Kazuo Watanabe, coord. Carlos Alberto Salles, São Paulo, Quartier Latin, 2009. 
SALLES, Carlos Alberto de. "Mecanismo alternativo de solução de controvérsias e acesso à justiça: a inafastabilidade da tutela jurisdicional recolocada", in Processo e Constituição: Estudos em Homenagem ao Professor José Carlos Barbosa Moreira (Coordenação Luiz Fux, Nelson Nery Júnior e Teresa Arruda Alvim Wambier). São Paulo, Revista dos Tribunais, 2006.

. "Class actions: algumas premissas para comparação", in Revista de Processo, n. 174, São Paulo, Revista dos Tribunais, 2009.

SANTOS, Lia Justiniano dos. "A introdução da mediação no Judiciário paulista através do Setor de Conciliação do Tribunal de Justiça do Estado de São Paulo", in Revista do Advogado, n. 87, São Paulo, Associação dos Advogados de São Paulo, 2006.

SARLET, Ingo Wolfgang. "Valor de Alçada e Limitação do acesso ao Duplo Grau de Jurisdição: Problematização em nível Constitucional, à Luz de um conceito material de direitos fundamentais", in Revista da Ajuris, n. 66, Porto Alegre, 1996.

SCARPINELlA BUENO, Cássio. O Poder Público em Juízo, $5^{\text {a }}$ edição, São Paulo, Saraiva, 2009.

A nova etapa da reforma do código de processo civil, vol. $2,2^{\text {a }}$ edição, São Paulo, Saraiva, 2006.

SEGOVIA, Rafael Hinojosa (coord). Sistemas de Solución ExtraJurisdiccional de Conflictos, Madrid, Ramón Areces, 2006.

SIFUENTES, Mônica. Súmula Vinculante - Um Estudo sobre o Poder Normativo dos Tribunais, São Paulo, Saraiva, 2005.

SILVA, Carlos Manuel Ferreira da. "Breves notas sobre a uniformização da jurisprudência cível em Portugal”, in Revista de Processo, n. 117, São Paulo, Revista dos Tribunais, 2004. 
SILVA. Paula Costa e. "A ordem do Juízo de D. João III e o regime processual experimental", in Revista de Processo, n. 156, São Paulo, Revista dos Tribunais, 2008.

"O acesso ao sistema judicial e os meios alternativos de resolução de controvérsias: alternatividade efectiva e complementariedade", in Revista de Processo, n. 158, São Paulo, Revista dos Tribunais, 2008.

SILVA, Paulo Eduardo Alves da. Condução Planejada dos processos judiciais - a racionalidade do exercício jurisdicional entre o tempo e a forma do processo, Tese de Doutorado apresentada na Faculdade de Direito da Universidade de São Paulo, 2005, inédita.

. "Gerenciamento de processos e cultura de litigância - a experiência do 'casa management' inglês", in As grandes transformações do Processo Civil Brasileiro: Homenagem ao Professor Kazuo Watanabe, coord. Carlos Alberto Salles, São Paulo, Quartier Latin, 2009.

SORIANO, Leonor Moral. El Precedente Judicial, Madrid, Marcial Pons, 2002.

SOSA, Ángel Landoni. "New information Technologies in Civil Procedure Synthesis Report", in Direito Processual Comparado, organizado por Ada Pellegrini Grinover e Petrônio Calmon Filho, Rio de Janeiro, Forense, 2007.

SOUSA, Miguel Teixeira de. "Um novo Processo Civil português: à la recherche du temps perdu?", in Revista de Processo, n. 161, São Paulo, Revista dos Tribunais, 2008.

SOUZA, Arthur César de. "Análise da problemática jurídica dos novos anteprojetos de lei de execução fiscal: aspectos inovadores e controvertidos", in Revista de Processo, n. 166, São Paulo, Revista dos Tribunais, 2008.

Superior Tribunal de Justiça. Disponível em <www.stj.jus.br> Acessos em 23/11/2009, 02/08/2009 e 15/12/2009. 
Supremo Tribunal Federal. Disponível em <www.stf.jus.br> Acesso em 10/11/2009.

TALAMINI, Eduardo. "O primeiro esboço de um novo CPC", disponível em $<$ www.migalhas.com.br> Acesso em 21/12/2009.

TANIGUCHI, Yasuhei. "O Código de Processo Civil Japonês de 1996 - Um Processo para o próximo século?", in Revista de Processo, n. 99, São Paulo, Revista dos Tribunais, 2000.

"Japan's recent civil procedure reform: its seeming success and left problems", in The reforms of civil procedure in comparative perspective, coord. Nicolò Trocker and Vicenzo Varano, Torino, Giappichelli, 2005.

TARTUCE, Fernanda. Mediação nos Conflitos Civis, São Paulo, Método, 2008.

TARUFFO, Michele. "Precedente ed esempio nella decisione giudiziaria", in Rivista Trimestrale di Diritto e Procedura Civile, anno XLVIII, n. 1, Milano, Giuffrè, 1994.

"Recent and current reforms of civil procedure in Italy", in The reforms of civil procedure in comparative perspective, coord. Nicolò Trocker and Vicenzo Varano, Torino, Giappichelli, 2005.

TARZIA, Giuseppe. "La durata del processo cicile e la tutela dei deboli" in Estudos de Direito Processual Civil - Homenagem ao Professor Egas Dirceu Moniz de Aragão, São Paulo, Revista dos Tribunais 2005.

. "O novo processo civil de cognição na Itália', in Revista da Ajuris, n. 65, Porto Alegre, 1995.

TEIXEIRA, Sálvio de Figueiredo. "A Súmula Vinculante e sua evolução no Brasil”, in Revista Trimestral de Jurisprudência dos Estados, v. 179, São Paulo, Jurid Vellenich, 2000. 
TESHEINER, José Maria Rosa. "Em tempos de reformas - o reexame de decisões judiciais”, in Revista de Processo, n. 147, São Paulo, Revista dos Tribunais, 2007.

THEODORO JÚNIOR, Humberto. "As nulidades no Código de processo Civil", in Revista de Processo, n. 30, São Paulo, Revista dos Tribunais, 1983.

. "Celeridade e efetividade da prestação jurisdicional. Insuficiência da reforma das leis processuais", in Revista de Processo, n. 125, São Paulo, Revista dos Tribunais, 2005.

. "Inovações da Lei 10.352/2001, em matéria de Recursos Cíveis e Duplo Grau de Jurisdição", in Aspectos polêmicos e atuais dos recursos e de outros meios de impugnação às decisões judiciais, coordenação de Teresa Arruda Alvim Wambier e Nelson Nery Junior, vol. 6, São Paulo, Revista dos Tribunais, 2002.

.NUNES, Dierle e BAHIA, Alexandre. "Litigiosidade em massa e repercussão geral no recurso extraordinário", in Revista de Processo, n. 177, São Paulo, Revista dos Tribunais, 2009.

Tribunal de Justiça de São Paulo. Disponível em <www.tj.sp.gov.br>.

TROCKER, Nicolò. "Il nuovo articolo 111 della costituzione e il giusto processo in matéria civile: profili generali”, in Rivista Trimestrale di Diritto e Procedura Civile, anno LV, n. 2, Milano, Giuffrè, 2001.

. VARANO, Vincenzo. The reforms of civil procedure in comparative perspective, Torino, Giappichelli, 2005.

TUCCI, José Rogério Cruz e. Tempo e Processo. São Paulo, Revista dos Tribunais, 1997. "O problema da lentidão da justiça e a questão da súmula vinculante", in Revista do Advogado, São Paulo, AASP, 2004. 
Precedente Judicial como Fonte do Direito, São Paulo, Revista dos Tribunais, 2004

“A 'Repercussão Geral' como pressuposto de admissibilidade do Recurso Extraordinário", in Meios de Impugnação ao julgado civil: Estudos em Homenagem a José Carlos Barbosa Moreira, Coord. Adroaldo Furtado Fabrício, Rio de Janeiro, Forense, 2007.

"Eficácia do precedente judicial na história do direito brasileiro", in Revista do Advogado, n. 78, São Paulo, AASP, 2004.

. "Duração Razoável do Processo (art. 5, LXXVIII, da Constituição Federal)”, in Processo Civil - Notas Tendências - Homenagem ao Professor Humberto Theodoro Júnior, coord. Fernando Gonzaga Jayme, Juliana Cordeiro de Faria e Maíra Terra Lauar, Belo Horizonte, Del Rey, 2008.

VAZ, Alexandre Mário Pessoa. Direito Processual Civil, do Antigo ao Novo Código Novas Tecnologias ao serviço da Justiça, 2. ed., Coimbra, Almedina, 2002.

VIANA, Flávia Batista. “Algumas considerações sobre as class actions norte-americanas (pequenos contrapontos com as ações coletivas brasileiras)", in Revista de Processo, n. 159, São Paulo, Revista dos Tribunais, 2008.

VIANA, Juvêncio Vasconcelos. Efetividade do Processo em face da Fazenda Pública, São Paulo, Dialética, 2003.

VIGORITI, Vicenzo. "L'uso giurisprudenziale della comparazione giuridica", in Revista de Processo, n. 123, São Paulo, Revista dos Tribunais, 2005.

Di alcuni recenti interventi sul diritto comparato", in Revista de Processo, n. 154, São Paulo, Revista dos Tribunais, 2007. 
WALTER, Gehard. "The German civil procedure reform act 2002: much ado about nothing?", in The reforms of civil procedure in comparative perspective, coord. Nicolò Trocker and Vicenzo Varano, Torino, Giappichelli, 2005.

WAMBIER, Teresa Arruda Alvim. "Súmulas e inadmissibilidade da apelação" in Direito e Processo: Estudos em Homenagem ao Desembargador Norberto Ungaretti, Coord. Pedro Manoel Abreu e Pedro Miranda de Oliveira, Florianópolis, Conceito Editorial, 2007.

WATANABE, Kazuo. "Cultura da Sentença e Cultura da Pacificação", in Estudos em Homenagem à professora Ada Pellegrini Grinover, coordenação Flávio Luiz Yarshell e Maurício Zanóide de Moraes, São Paulo, DPJ, 2005.

. "Relação entre demanda coletiva e demandas individuais", in Direito Processual Coletivo e o anteprojeto de Código Brasileiro de Processos Coletivos, Coordenação de Ada Pellegrini Grinover, Aluisio Gonçalves de Castro Mendes e Kazuo Watanabe, São Paulo, Revista dos Tribunais, 2007.

"Demandas Coletivas e os problemas emergentes da práxi forense", in as Garantias do Cidadão na Justiça, coord. Sálvio Figueiredo Teixeira, São Paulo, Saraiva, 1993.

YARSHELL, Flávio Luiz. “A Reforma do Judiciário e a promessa de duração razoável do processo", in Revista do Advogado, São Paulo, AASP, 2004.

. "Processos com objetos idênticos e excesso de recursos: alternativa para atenuar a morosidade dos julgamentos nos Tribunais", in Jornal Carta Forense, Novembro de 2006.

- "Para pensar a Semana Nacional de Conciliação", in Jornal Folha de São Paulo, edição do dia 08/12/2009, p. A3. 
ZANFERDINI, Flávia de Almeida Montingelli. "A crise da justiça e do processo e a garantia do prazo razoável", in Revista de Processo, n. 112, São Paulo, Revista dos Tribunais, 2003.

ZUCKERMAN, Adrian A.S., "Court Control and party compliance - the quest for effective litigation management", in The reforms of civil procedure in comparative perspective, coord. Nicolò Trocker and Vicenzo Varano, Torino, Giappichelli, 2005.

Justice in Crisis: Comparative Dimensions of Civil Procedure, New York, Oxford, 1999. 